\title{
ARCHAEOLOGICAL RESEARCH RESULTS OF THE SETTLEMENT MICRO-REGION IN THE AREA OF ULÓW IN MIDDLE ROZTOCZE IN THE LIGHT OF THE PROJECT "ROZTOCZE - THE ANCIENT TERRA INCOGNITA?..."
}

\section{BARBARA NiEZABITOWSKA-WIŚNIEWSKA}

A u t h o r's a d d r e s s: Institute of Archaeology, Maria Curie-Skłodowska University, Plac Marii Curie-Skłodowskiej 4, 20-031 Lublin, e-mail: barbara.niezabitowska-wisniewska@poczta.umcs.lublin.pl; baica@poczta.onet.pl

A b s t r a c t. Many years of archaeological research near Ulów in the Middle Roztocze contributed to the discovery of a multicultural settlement complex, functioning from the Palaeolithic to the $17^{\text {th }} / 18^{\text {th }}$ century, refuting the existing myth of Roztocze as a white spot on the map of prehistoric settlement. The results of an archaeological research became the basis for the implementation of the project "Roztocze - the ancient terra incognita? (Settlement micro-region in the area of Ulów in Middle Roztocze in the prehistory and its background. Interdisciplinary studies)". Comprehensive and interdisciplinary research has enabled the reconstruction of settling processes in the micro-region of Ulów in prehistory and in the Modern Age. The main reason for the rise of a multicultural enclave, encompassed by areas devoid of traces of the prehistoric settlement, should be seen in the favourable environmental conditions. Many aspects of the ritual and everyday life of particular archaeological cultures populations recorded in Ulów, do not find analogies in other areas of Poland. A series of several dozen radiocarbon dates confirmed all the stages of the Ulów micro-region settlement recorded in the archaeological sources. It also highlighted a whole range of the problems related to the interpretation of some cultural phenomena, especially with regard to the intensive settlement of the Corded Ware culture and the Wielbark culture, as well as the early phase of the Migration Period and initial phases of the early Middle Ages.

K e y w o r d s: Ulów, Middle Roztocze, settlement micro-region, Prehistory, Modern Age, interdisciplinary research

\section{INTRODUCTION}

Ulów (Tomaszów Lubelski commune, Tomaszów Lubelski District, Lublin Voivodeship) is a small village located at the foot of Wapielnia (385 meters above the sea level), the highest elevation of the Middle Roztocze, also known as Roztocze Tomaszowskie. The village is surrounded by a compact forest complexes, which intensifies 

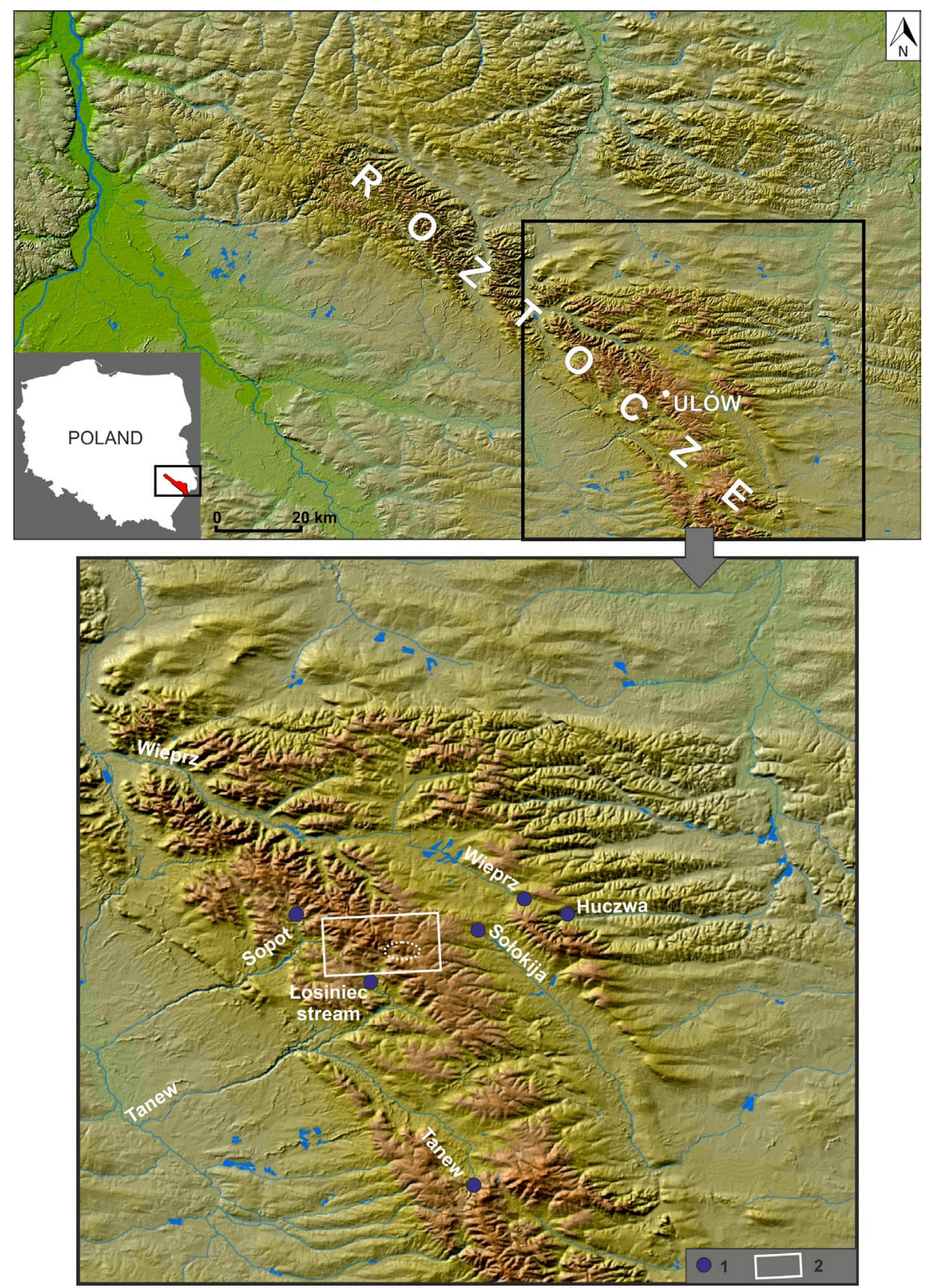

Fig. 1. Location of the Ulów village on the background of the map of Roztocze (GAWRYSIAK 2004). 1 - the springs of the region main rivers; 2 - the range of the Ulów micro-region and its immediate vicinity presented on figure 2 (the approximate range of the archaeological sites occurrence is marked with a dashed line)

its modern "isolation" (Fig. 1, 2B). Many years of the archaeological research lead to the discovery of a group of multicultural archaeological sites in the vicinity of Ulów (Fig. 2A). 

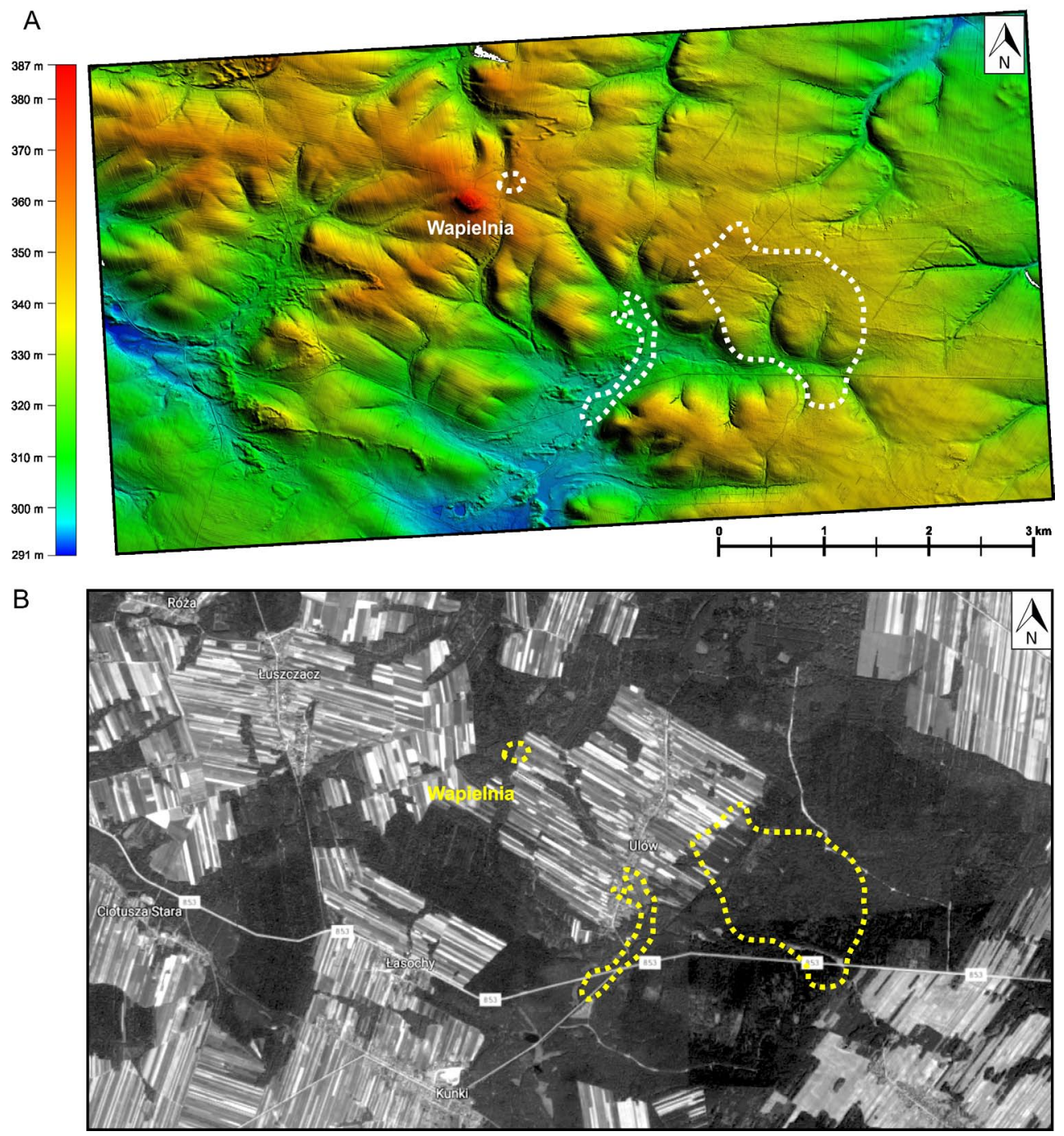

Fig. 2. The Ulów micro-region and its immediate vicinity (the approximate range of the archaeological sites occurrence is marked with a dashed line). A - Digital Terrain Model; B - satellite image with visible range of the forests around Ulów (source: www.google.pl)

\section{HISTORY OF RESEARCH}

Surface surveys conducted in the area of Ulów in the autumn of 1994 as a part of the Archaeological Picture of Poland program (AZP 94-88, 94-89; JASKANIS 1996; KozIOŁ et al. 2012), allowed to single out the two archaeological sites (settlement traces $^{1}$ ). Unfortunately, these studies were limited only to non-forested areas, in the

1 Site 1 - chip made of Volhynian flint, prehistory, unspecified chronology and exact location; site $2-2$ pieces of Modern Age ceramics. 
immediate vicinity of the village. In 2001 a collection of several hundred metal artefacts, dated back to the Roman Period, Migration Period and the early Middle Ages, went into the Regional Museum of Dr. J. Peter in Tomaszów Lubelski (the so-called "Ulów collection"). These objects were found with the use of metal detectors by the militaria hunters, seeking for a weapons from World War II in the forest near Ulów. The field survey, conducted with their participation in 2001-2002 allowed the identification of 9 previously unknown archaeological sites (No. 3, 6-10, 12-14), from which some of the metal artefacts comes. In the course of these field activities on site 3 , the presence of one barrow was registered. Three other barrow sites were also discovered (sites No. 4, 5, 11), wherein within site No. 4 three earth mounds, within site No. 5 two earth mounds, and within the site No. 11 one earth mound were recorded. Repeated surface surveys within the forest complex and in the neighbouring farmland, conducted by the Provincial Heritage Monuments Protection Office in Zamość, allowed for the record of 9 further archaeological sites (sites No. 15-23), including 4 barrow sites (sites No. 20-23) - (BAGIŃSKA, NieZABitowsKa 2003, 2004; KокоWSKi 2003: 14-15, phot. 5, 6; 2005a: 530-531; 2005b: 167, fig. 2 : c, g-k; 3: d-f; 2005c: 42-43, fig. 22, 23; 2007a: 28-30, fig. 3; 2007b: 223, fig. 98; NiEZABITOWSKA 2003a, 2004, 2005b: 85-86, fig. 5, 6; NiEZABitowsKA-WiśNIEWSKA 2007: 5 , phot. $4-13$, fig. $2-4$; 2008).

In the autumn of 2001, the first survey excavations were carried out in one of the places indicated by the militaria hunters (site No. 3), confirming the existence of the Wielbark culture cemetery. In 2002 systematic excavation research has begun. Until 2013, seven archaeological sites had been excavated and identified in various extent (sites No. 3, 4, 6-10), while at the same time their ranges specified by the militaria hunters were partially verified (NIEZABITOWSKA 2003b, 2005a; NiEZABITOWSKA-WIŚNIEWSKA 2007, 2008, 2009: 201-202, 2012; WIŚNIEWSKI 2007; NIEZABITOWSKA-WIŚNIEWSKA, WIŚNIEWSKI 2011; in print).

\section{THE PROJECT AND ITS SPECIFICITY}

In 2014 started the implementation of the project titled "Roztocze - the ancient terra incognita? (Settlement micro-region in the area of Ulów in Middle Roztocze in the prehistory and its background. Interdisciplinary studies)" financed from the funds of the National Science Centre, granted on the basis of decision number DEC2013/09/B/HS3/03352. The title of the project was not accidental. Before the began of archaeological research in Ulów, it was widely accepted that the Roztocze area was a place inconvenient for the prehistoric settlement. As the main reasons for this state of affairs was given the lack of the surface water and difficult access to the groundwater, a varied shape of the terrain and its height above sea level, and significant forestation, characteristic primarily for the central part of the region. The reluctance to settle Roztocze was particularly intense during the Roman Period and Migration Period, what is reflected in a number of publications and maps of the such dated settlement 
(GodŁowsKi 1985; Kunisz 1985: map 1-6; KoKowsKi 1988a, b, 1991: fig. 81; compare - NieZABitowsKa 2005b; NieZABITOWSKA-WiŚNIEWSKA 2009).

Thus, the Roztocze area was also unlucky for large-scale excavation research. The works were carried out randomly and to a small extent. Few exceptions in the recognition of the Roztocze area are the results of research conducted within the so-called Lubaczów expedition in the 1950s, mainly concentrated in the basins of the upper Tanwia, upper Sołokija, Rata and Wieprz rivers. During this expedition, burial mounds of the Corded Ware culture in Łukawica, Brzezinki and Lipie (Narol commune) were excavated, as well as barrows dated back to the Roman Period in the first of mentioned villages (MACHNIK 1959, 1960, 1961; Machniк, Ротоскі 1959a, b; Ротоскі 1960; RogozińSKa, Ротоскі 1959; KoKOwsKi 1988c). Works were also carried out at the barrow cemetery in Guciów (Zwierzyniec commune). Excavated burial mounds are connected with the Corded Ware culture, Trzciniec culture and the early Middle Ages (RogozińsKA 1963; ZoLLADAMIKowA 1975: 80-91). The burial mound of the Trzciniec culture was excavated at the barrow cemetery in Dominikanówka (Krasnobród commune), and the alleged grave of this culture in the village of Kaczórki (Krasnobród commune) - (TARAS 1995: 52-53 List III, 220, 224 - further literature there). Noteworthy is also the study of prehistoric artefacts from the collection of J. Sitek, originating from the area extending between Krasnobród and Guciów, supplemented by a surface surveys and test excavations (BALCER et al. 2002; Koman 2002). In 2002, excavation research was started at a multicultural site No. 22 in Łukawica, where the remains of Early Medieval settlement and less numerous materials from the Bronze Age, the Roman Period and Migration Period were discovered (Piotrowski 2004, 2008). Most of the activities described above were limited to the northern and southern outskirts of Roztocze. The list of discoveries from its area is also supplemented by random finds, including Roman coins, largely acquired at the end of the $19^{\text {th }}$ and the beginning of the $20^{\text {th }}$ century, or discovered during surface surveys (compare NiEZABITOWSKA 2005b; GŁADYSZ-JuŚCIŃSKA, JUŚCIŃSKI 2010: fig. 1).

The term "settlement micro-region in the area of Ulów" included in the title of the project "Roztocze - the ancient terra incognita? ..." should be understood as the area surrounding the modern village of Ulów, mainly a large forest complex extending to the east from the village estates, covered by an intense and multicultural prehistoric settlement. Therefore, the project assumed a detailed recognition of all settlement stages represented in this micro-region. The term "background" should be understood in two ways - as the environmental conditions of settlement in the Ulów micro-region and as a picture of the cultural situation in prehistory of Roztocze, with particular emphasis on Middle Roztocze and adjacent areas, mainly on the poorly recognized Bełz Plain. A series of artefacts, obtained as a result of illegal searches with the use of metal detectors, currently deposed in the Regional Museum of Dr. J. Peter in Tomaszów Lubelski, shed a new light on that last issue. They come from villages distant from Ulów by 4 to $30 \mathrm{~km}$, including from Justynówka (Tomaszów Lubelski commune), Łuszczacz (Susiec commune), Machnów Nowy, Machnów Stary and Wierzbica (Lubycza Królewska commune) - (NiEZABitowsKAWIŚNIEWSKA 2009: 203, fig. 26: 1-2, 7-9). 
The main goal of the "Roztocze - the ancient terra incognita?..." project was the reconstruction and interpretation of the prehistoric settlement processes in the vicinity of the Ulów village, based on the results of interdisciplinary research. The basis of the project was the analysis of materials acquired during the archaeological excavation research, carried out in Ulów in the years 2001-2013, supplemented by the results of new field research, carried out during the project implementation. In order to achieve the intended goal, it was necessary to conduct the archaeological recognition to the highest possible degree in the areas around Ulów, and record the range of the settlement micro-region, as well as to determine the chronology of particular archaeological sites, on the basis of a typological method, supplemented with a series of radiocarbon dating (Moskal-Del Hoyo et al. 2017).

\section{METHODS OF RESEARCH}

During the project implementation, the archaeological excavations and surface surveys were carried out. The excavation works focused on the continuation of the already known archaeological sites recognition, as well as on studies of sites known so far only from the militaria hunters references or from surface surveys. The research was also conducted in places previously not excavated, located outside the range of known sites, including outside forest areas. Most of these works were of a survey nature. In the cases where the prehistoric settlement was confirmed, the range of research was extended and continued within a larger plane. Excavations were supplemented or preceded by the geological and geomorphological sampling, geophysical surveys using the magnetometry (outside forest areas), analysis of the Digital Terrain Model (hereinafter DTM) and analysis of archival maps from the late $18^{\text {th }}-$ early $20^{\text {th }}$ centuries.

During the excavation studies, numerous samples of organic matter were taken for anthropological, anthracological, paleobotanical, archeozoological, mineralogical and petrographic research, as well as for radiocarbon dating. They significantly supplemented the set of samples obtained before the project, in the years 2001-2013.

In the spring and autumn seasons, verification surface surveys were carried out using GPS, repeating them in each of the research seasons.

A series of geological and geomorphological samplings were also carried out in the surroundings of Ulów - in Jeziernia, Łuszczacz and in the nature reserve of "Piekiełko" near Tomaszów Lubelski. In the last of the sites also excavation surveys were conducted (NiTYCHORUK et al., in preparation for printing).

Apart from strictly archaeological studies (see also WIŚNIEWSKI 2017), during the project implementation a whole spectrum of analyzes and research was carried out, based on the achievements and methods of the other fields of science. The results of some of them are presented in this volume: anthropological research (SzCZUROWSKI 2017); paleobotanical (analysis of plant macro-remains, analysis of charcoal, palynology) - (PIDEK et al. 2017); geomorphological and geological (geomorphological and geological mapping, geological surveys, terrain relief models) - (RoDzIK, 
Nitychoruk 2017); use-wear analysis (Pyżewicz 2017). The results of other studies will be included in other planned publications. These are: archaeozoological (WILCZYŃSKI 2017); mineralogical-petrographic research (HUBER 2014; NiTYCHORUK 2017); geophysical surveys (PosPIESZNY 2015); chemical analysis of glass (BIBORSKI, BIBORSKi 2017); DTM image analysis (BUDZISZEwSKI, JAKUBCZAK 2017; BudZISZEWSKI, SzUBSKI 2017); physicochemical analyzes of sediments (MroczeK 2014); fabric analysis (MaIK 2014); mycological research (PAWŁOWSKa 2017).

\section{RESULTS}

In this article, it is impossible to discuss the results of all archaeological research, a separate monograph and a number of articles will be devoted to the settlement complex in Ulow in the light of specific issues. Thus, the general results of the research and the most important problems related to the interpretation of settlement processes in the Ulów micro-region will be presented here.

\section{The number of archaeological sites}

As already mentioned, before starting the project "Roztocze - the ancient terra incognita? ..." seven archaeological sites were excavated in varying degree (sites No. 3, 4, 6-10). During the project implementation, studies on them were continued, but also the research on subsequent, recorded sites were initiated (sites No. 5, 13, 14, 17, 20, 21). The archaeological surveys also allowed the discovery of three new sites (No. 25-27). The next three sites (No. 28-30) were discovered during surface surveys on the farmlands.

As a result of surface surveys and excavations carried out after partial deforestation and plowing for new plantings, it was also possible to specify the ranges of three archaeological sites, significantly expanding them (site No. 3 by about $100 \mathrm{~m}$ towards the west; site No. 6 by about $50 \mathrm{~m}$ towards the east, about $140 \mathrm{~m}$ to the west and about $50 \mathrm{~m}$ to the south; site No. 9 about $80 \mathrm{~m}$ to the west).

At present, 30 archaeological sites are known in the Ulów settlement micro-region, of which 16 were excavated to varying degrees, 4 as a result of geological and geomorphological surveys and surface surveys, and 10 only on the surface surveys (Fig. 3).

\section{Cultural characteristics}

The historical material obtained during the archaeological research in the settlement micro-region of Ulów, undoubtedly indicates the functioning of the settlement from the Palaeolithic to the $17^{\text {th }}-18^{\text {th }}$ centuries. The Palaeolithic and Mesolithic settlement are poorest represented (sites No. 3, 20 and probably 17 and $21^{2}$ ) (Fig. 4A).

\footnotetext{
2 For the sake of data clarity, only those sites on which a representative number of artefacts and/or archaeological features were discovered, which with high probability can be attributed to a particular archaeological culture, were included in the list. Single or doubtful finds of particular cultures dispersed in various sites were not taken into account.
} 


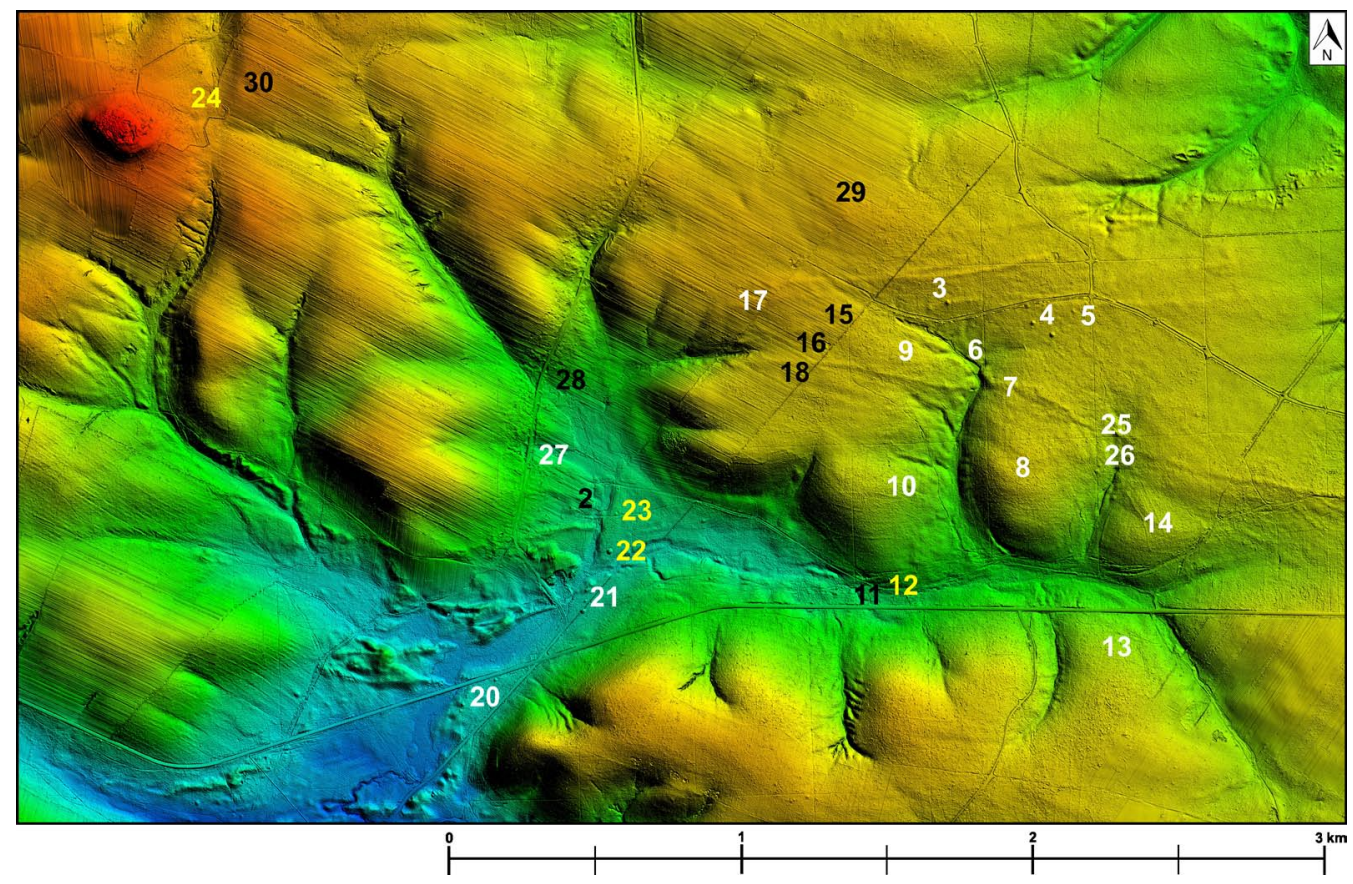

Fig. 3. The Ulów micro-region with marked location of archaeological sites; white numbers - sites excavated to a varying degree; yellow numbers - sites known from surface surveys and geological probing; black numbers - sites known only from surface surveys

The Neolithic period is represented by the following cultures: Lublin-Volhynian culture (hereinafter: L-VC, site No. 3, 7, 9) (Fig. 4B: 1); Funnel Beaker culture (hereinafter: FBC, sites No. 3, 6, 7, 9, 14, 17, 25, 26) (Fig. 4B: 2) and Corded Ware culture (hereinafter: CWC, sites No. 3-5, 20-22, 25, 26 and probably 23) (Fig. 5). Traces of settlement from the Bronze Age and the early Iron Age are connected with cultures: Mierzanowice culture (hereinafter: MC, sites No. 4, 21, 25) (Fig. 6A: 1); Trzciniec culture (hereinafter: TC, sites No. 3-5, 7, 16, 21, 26, 30) (Fig. 6A: 2) and Lusatian culture (hereinafter: LC, sites No. 3, 13, 17) (Fig. 6A: 3). Intensive settlement is also connected with the Roman Period and the early phase of the Migration Period and related to the Wielbark culture (hereinafter: WC, sites No. 3, 6, 7, 9, 10, 17, 27 and probably 15; and on the basis of artefacts from the so-called Ulów collection: No. 8, 13, 14) (Fig. 6B). During the archaeological research, also a few traces of Early Medieval settlement were discovered (sites No. 3, 18 and probably 12) (Fig. 7A: 1-2). It is much better represented in the so-called Ulów collection (without the possibility of assigning to a specific archaeological site) (Fig. 7A: 3). There were also numerous remains of modern settlement from $17^{\text {th }}, 18^{\text {th }}$ and $19^{\text {th }}$ centuries (sites No. 2, 3, 6, 7, 9, 11, 13, 25-28) (Fig. 7B). The prehistoric materials recorded without the possibility of indicating their cultural affiliation were discovered on two sites (No. 1, 29). The chronology of a single barrow on the site No. 24 cannot be determined. Geological surveys indicate only that it is a prehistoric mound (Fig. 3). 

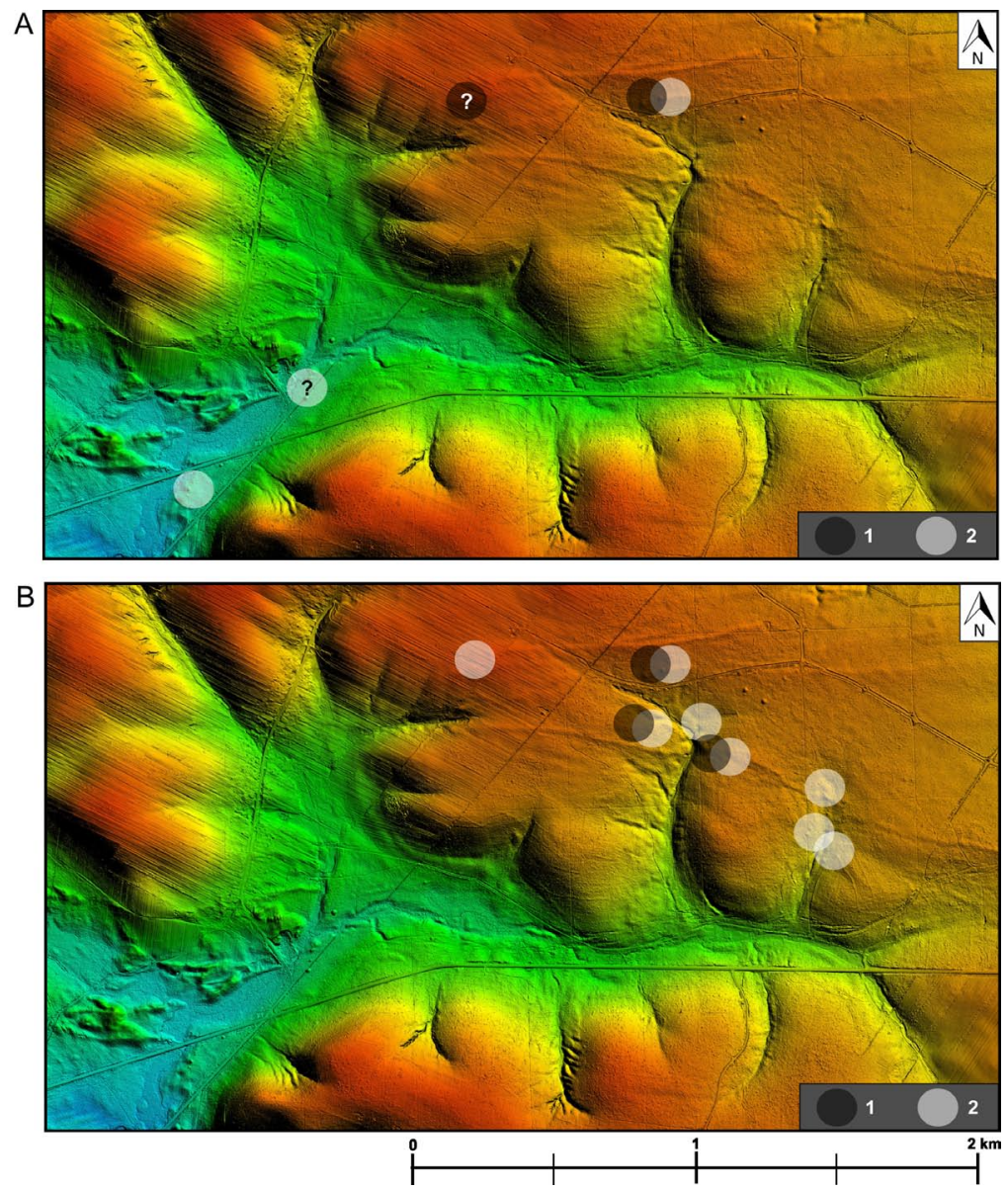

Fig. 4. A - range of the Palaeolithic (1) and Mesolithic settlement occurrence (2) - (question mark - uncertain sites); B - range of the Lublin-Volhynian culture (1) and Funnel Beaker culture (2) settlement occurrence

\section{Spread of the sites}

The archaeological sites in the Ulów settlement micro-region are located in two different landscape zones - on the hilltop plateau and on the terraces in the bottom of the valley. Their location, regardless of the zone, is closely related to the system of stream-valleys, currently dry or flowing only periodically, which most likely provided easy access to water. Settlement on the plateau focuses mainly on both sides of the valley of a small stream, called Zierąbek, where in the 1940s and 1950s water was drawn, and the cattle were grazed north from its spring (in place of site No. 3). Some of the sites are also located on both sides of the dry valley located at a distance of about $450 \mathrm{~m}$ east from the Zierąbek stream. The sites in the southern and south-eastern part of the research area are located on the dunes at the bottom of a vast, highly branched and mostly swamped valley, with numerous ponds of stagnant water. This 

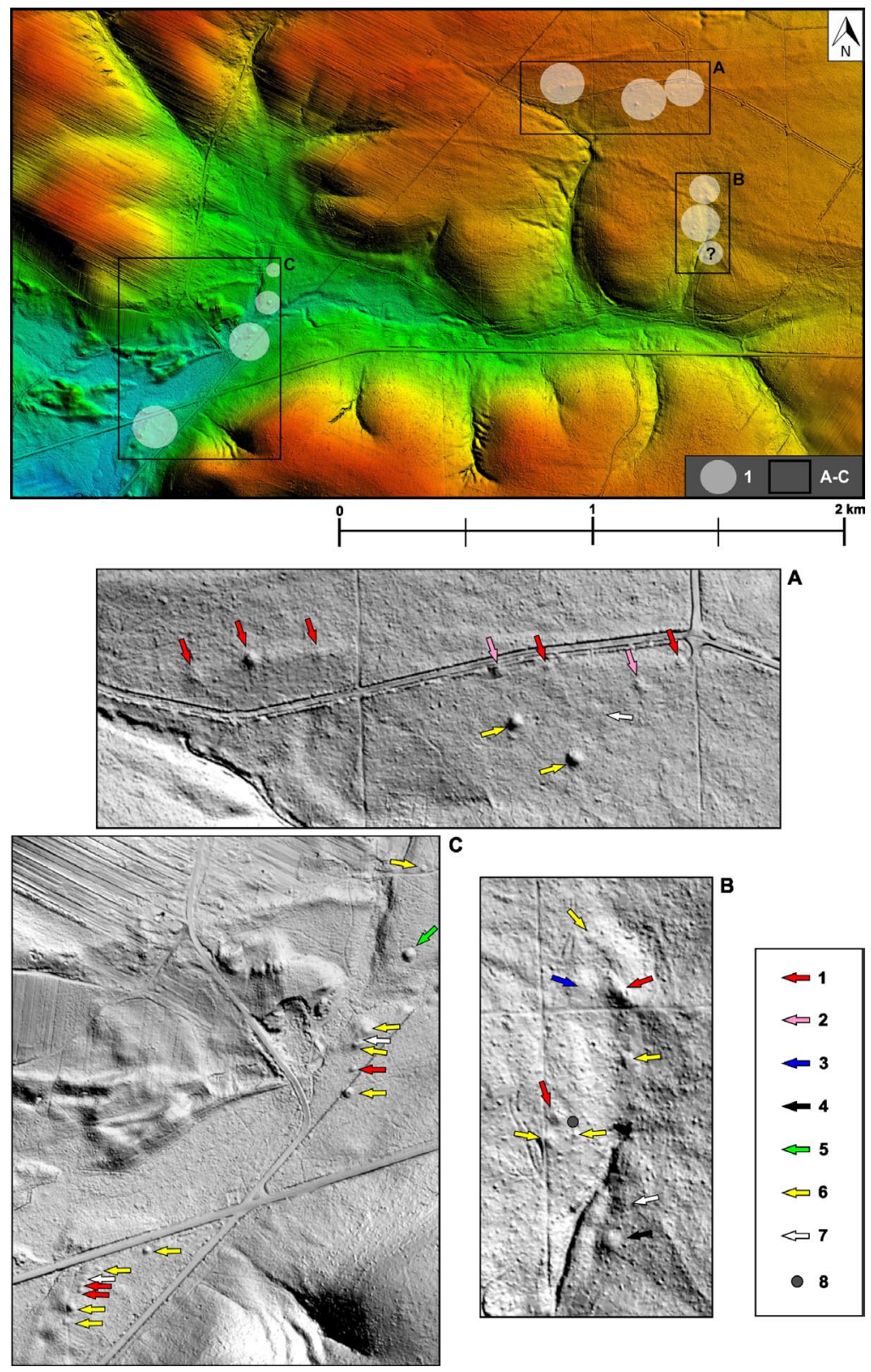

Fig. 5. Range of the Corded Ware culture settlement occurrence (1 - archaeological sites, A-C - barrow fields). A - burial mounds on sites No. 3, 4 and 5; B - burial mounds on sites No. 14, 25 and 26 (question mark - uncertain site); C - burial mounds on sites No. 20, 21, 22 and 23. 1 - barrows excavated with central burial pits; 2 - barrows tested by the survey; 3 - an alleged barrow, heavily damaged and excavated; 4 - excavated barrow of undetermined chronology; 5 - barrow geologically probed and radiocarbon dated; 6 - barrows geologically probed; 7 - alleged barrows, almost invisible in the field; 8 - a flat grave of the Corded Ware culture 

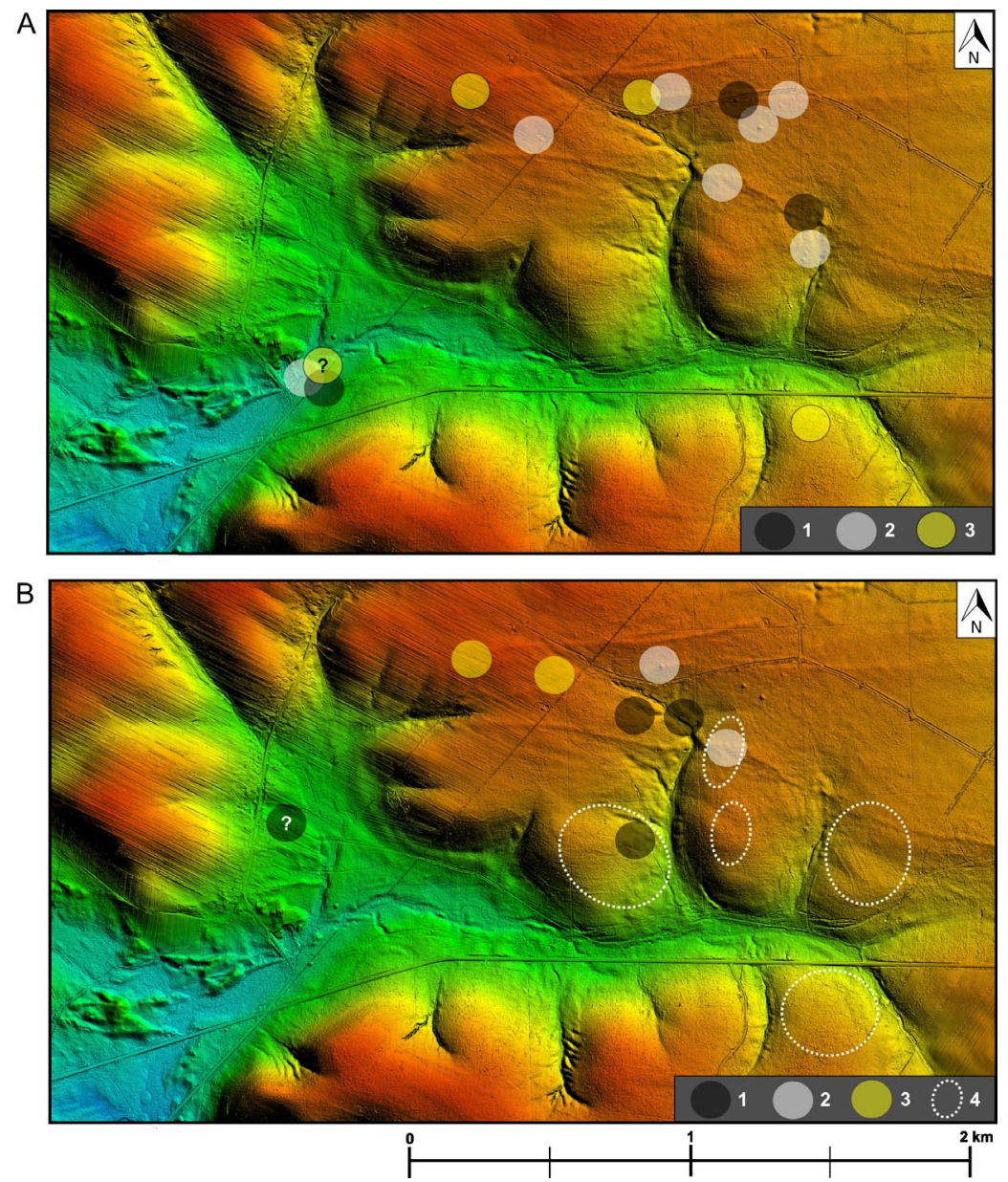

Fig. 6. A - range of the settlement occurrence from the Bronze Age and early Iron Age. 1 - Mierzanowice culture; 2 - Trzciniec culture; 3 - Lusatian culture (question mark - uncertain site). B - range of the settlement from the Roman Period and the early phase of Migration Period (Wielbark culture). 1 - settlements (question mark - a destroyed site of uncertain function); 2 - cemeteries; 3 - surface finds; 4 - ranges of the sites appointed by the militaria hunters, approximate discovery location of some artefacts from the so-called Ulów collection, dated back to the Roman Period and Migration Period

valley connects in the south of Ulów with the Losiniec stream valley, which springs are located near the village of Kunki (Susiec commune), about $2.5 \mathrm{~km}$ from Ulów (Fig. 1B, 2A, 3).

It is also possible to observe some preferences in the selection of areas for settlement by particular archaeological cultures. Palaeolithic settlement was recorded in the hilltop area within long, narrow dunes (sites No. 3 and perhaps 17) (Fig. 4A: 1). Traces of Mesolithic settlement were discovered in two landscape zones - on the hilltop (site No. 3) and on the dunes at the bottom of the valley (site No. 20 and probably 21) (Fig. 4A: 2; see also WIŚNIEWSKI 2017). 

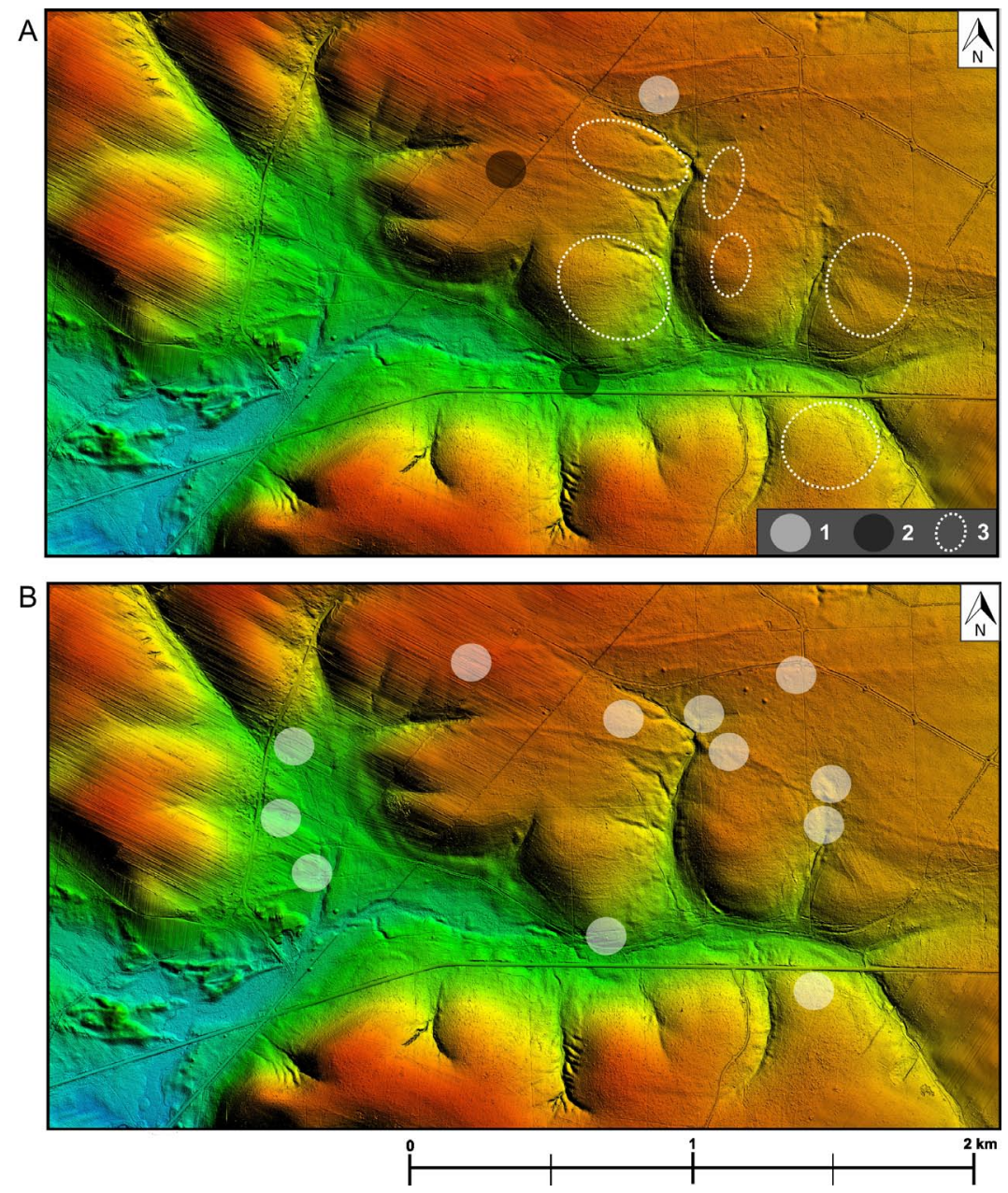

Fig. 7. A - range of the Early Medieval and Medieval settlement occurrence. 1 - materials from excavations; 2 - materials from surface surveys; 3 - ranges of the sites appointed by the militaria hunters, approximate discovery location of some artefacts from the so-called Ulów Collection, dated back to the Early Medieval and Medieval periods. B - range of the Modern Age settlement occurrence ( $17^{\text {th }}-19^{\text {th }}$ centuries)

L-VC materials are scattered over almost the entire research area, with the largest number of them concentrating on the hilltop near the sources of the Zierąbek stream (sites No. 3, 7, 9) (Fig. 4B: 1). This gives grounds to suppose that there were settlements of this culture. The settlement at site No. 3 was destroyed by the later settlement of FBC and CWC, and at the site No. 9 by the settlement of WC.

The FBC settlement is located mainly on the hilltop plateau (Fig. 4B: 2). Such dated single artefacts were discovered at almost all sites located there. The largest concentration of finds is related to sites No. 3 and 17. In the case of the first of them, the remains of the FBC settlement were destroyed by the CWC population, which, in order to obtain soil for erecting one of the mounds (barrow 2), levelled the area of 
the former FBC settlement. Therefore, the artefacts of this culture were found mainly in the humus layer and in the cultural layer of the site and in the huge number within the bank of barrow 2. Single preserved FBC features were discovered on the northern edge of the site. At site No. 17, there is a vast FBC settlement, partially destroyed in result of erosion processes related to modern agricultural activity and sand quarrying. Likewise, the traces of the FBC settlement recorded in other archaeological sites should be interpreted in a similar way.

The CWC sites are located in two distinctly different zones - on the hilltop (five sites) and in the bottom of the valley (four sites). This two CWC settlement enclosures are spaced about 1.5 to $2 \mathrm{~km}$ (Fig. 5).

The location of particular barrows on the hilltop reveals some differences. Three sites (No. 3-5) are located on a relatively flat part of it and in fact form two barrow fields, spaced about $150 \mathrm{~m}$ apart (Fig. 5A); two further sites (No. 25, 26) are located above the slope of a dry valley and should be interpreted as one barrow field (Fig. 5B). All CWC burial mounds are located on or in the immediate vicinity of the long, narrow dunes of the E-W or NW-SE direction.

The barrows at the bottom of the valley, separated into four archaeological sites (No. 20-23), form a series of mounds located in the direction of the valley course, extending from NE to SW. Most probably, some of them were destroyed during the construction of an asphalt road crossing the mentioned valley (Fig. 5C).

The number of barrows at particular sites, located on the hilltop plateau is as follows: site No. 3 - three burial mounds, all excavated (NIEZABITOWSKA-WIŚNIEWSKA, WIŚNIEWSKI 2011; in print); site No. 4 - five mounds, including one excavated, one surveyed, two geologically probed and one alleged; site No. 5 - two mounds, including one excavated and one surveyed (Fig. 5A); site No. 25 - two or three burial mounds, including one partially excavated, one geologically probed, one alleged, heavily damaged and excavated; site No. 26 - four mounds, including one excavated, three geologically probed and one flat grave (NIEZABITOWSKA-WiŚNIEWSKA et al., in preparation for printing) (Fig. 5B). At site No. 14 located on the western side of the dry valley, there are two further, poorly visible mounds, one of which was excavated. Due to the lack of historic material and the unusual construction of the central burial pit, it cannot be unambiguously related with the CWC.

The number of mounds on particular sites on the terrace in the bottom of the valley is as follows: site No. 20 - seven mounds, including two excavated, one alleged, other geologically probed; site No. 21 - four or five mounds, including one excavated, other geologically probed; site No. 22 - one barrow geologically probed and radiocarbon dated; site No. 23 - one geologically probed barrow (Fig. 5C).

Thus, there are at least 34 burial mounds in the area of Ulów. Thirteen CWC mounds were excavated, ten of them in whole or in the significant part, including central burial pits; two only by surveying, confirming the interpretation of the mound banks as CWC barrows; and one badly damaged by a survey. One burial mound was radiocarbon dated on the basis of a charcoal sample obtained by a geological probe. The remaining burial mounds, although only geologically probed, most likely also 
should be related with $\mathrm{CWC}^{3}$. This is evidenced by the sedimentation arrangement and development of the layers observed in the geological probes, including the nature of the fillings of central burial pits, recorded in some of them.

Remains of MC settlement, in the form of ceramic shards in the cultural layer and in one feature were discovered in the CWC mound banks or next to them. Like the burial mounds themselves, they are located in two zones - on the hilltop plateau and on the terrace in the bottom of the valley (Fig. 6A: 1).

Traces of TC settlement are scattered over the whole area of research, both in the hilltop part and in the bottom of the valley, in the south-western part of the research area (Fig. 6A: 2). Some of them are related to the older CWC mounds. At site No. 3, the TC vessel was buried in the CWC burial mound No. 2; at site No. 21, the materials of this culture were recorded in a ditch in the centre of the CWC burial mound and partially in the ceiling of the central burial pit. At site No. 3, the alleged grave of TC was also discovered, which could originally be covered with a burial mound, now completely levelled (NIEZABITOWSKA-WiŚNIEWSKA 2014a). Other TC artefacts are most likely related with the remains of settlements or camps of this culture.

Traces of LC settlement are limited to the hilltop part near the Zierąbek stream valley (Fig. 6A: 3). Perhaps during the Hallstatt Period, the settlement of this culture also functioned on the terrace in the bottom of the valley (site No. 21) and on a nearby dune, located about $60 \mathrm{~m}$ north from the site No. 21. This can be confirmed by two radiocarbon dates obtained for these places from charcoals (NITYCHORUK et al., in preparation for printing).

There are eleven archaeological sites related to the Roman Period and the early phase of the Migration Period settlement. Most of them are located in the hilltop plateau (Fig. 6B). Among them are three settlements (sites No. 6, 9, 10) and two WC biritual cemeteries (sites No. 3, 7). Settlements on sites No. 9 and 10 and cemeteries on sites No. 3 and 7 are separated by a deep valley of Zierąbek stream. Cemeteries are located on north and east, and settlements on south and west from the valley. Settlements are distanced about $150 \mathrm{~m}$ from cemeteries in the case of relation between sites No. 3 to 9 and about $130 \mathrm{~m}$ in the case of sites No. 7 to 9 . Thus, we can talk about two clearly separated zones - the sacrum and the profanum. The location of site No. 6, on which most likely the production part of the settlement of site No. 9 were discovered, and the single half-dugout from the early phase of the Migration Period, located on the other side of the valley, differs from this rule. Site No. 6 is located on the northern side of the Zierąbek valley, on a clear terrain flattening, extending along the valley edge on its NW-SE section. WC cemeteries on sites No. 3 and 7 are distanced about 300 m (NIEZABITOWSKA 2007; NIEZABITOWSKA-WiŚNIEWSKA 2008, 2009, 2012, 2014b, 2015a, b) (Fig. 6B).

\footnotetext{
3 Most probably except of a single mound on site No. 11, which on the basis of geological probing can be interpreted as a Modern Period border-mound. It is also difficult to determine the cultural affiliation of a single, undoubtedly prehistoric mound in the site No. 24, at the foot of the Wapielnia. However, two stone axes which can be related to CWC, found by the residents of Ulów, come from fields near this hill. This fact may indirectly indicate the same affiliation to the mentioned single burial mound.
} 
From three other archaeological sites located on the hilltop (No. 8, 13, 14) only artefacts from the so-called Ulów collection originate, dating back to the Roman Period and Migration Period. During the excavation research within them, so far it has not been possible to confirm the presence of such a dated settlement (Fig. 6B: 4).

Only one WC site (No. 27) is located at a considerable distance (about $1.25 \mathrm{~km}$ ) from the above mentioned cluster of such dated sites. It is located in the centre of the modern village on a small meadow hill, within a vast valley. A significant degree of the destruction of discovered materials by later modern settlement, makes it difficult to determine the function of this site. It seems, however, that it should be interpreted as a settlement of the Wielbark culture (Fig. 6B: 1).

In the micro-morphological DTM image, in several places within the research area, the traces of prehistoric fields were recorded, on falling south gentle slopes. They are in the form of "Celtic Fields", ploughed in a envelope-shape, but are heavily damaged by younger roads. They are located in the place of archaeological sites No. 10 and 14 (Fig. 8). Unfortunately, at the current stage of the research it is difficult to explicitly refer to their chronology. Due to the presence of the Roman Period settlement in the immediate vicinity, the relation of prehistoric fields traces with such dated settlement cannot be excluded (RoDzIK et al. 2017).

Few artefacts and much more numerous radiocarbon dates obtained from charcoal samples dated back to the early Middle Ages come mainly from site No. 3, located in the hilltop plateau (Fig. 7A: 1). From the same area most probably originate such

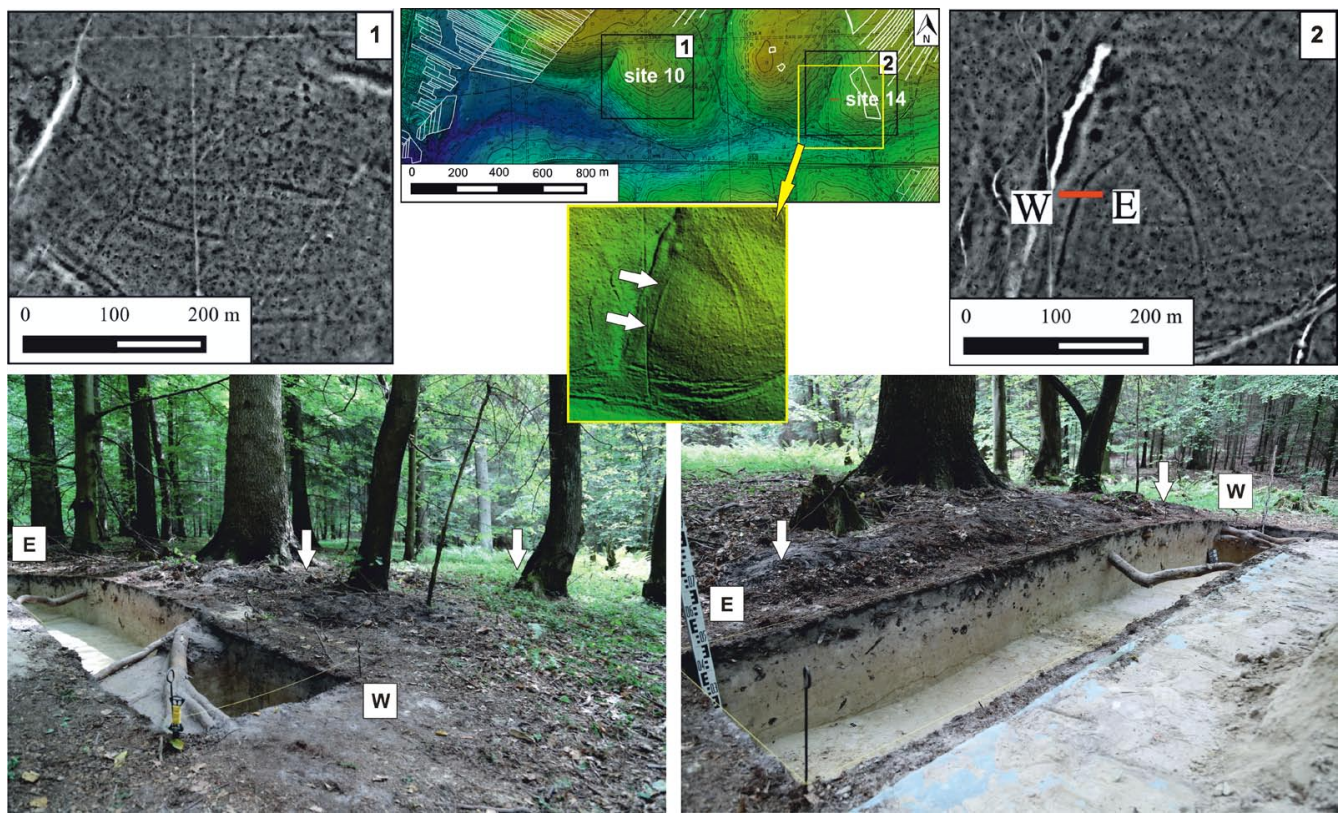

Fig. 8. Traces of prehistoric fields, so-called "Celtic fields" in the southern part of the research area (according to RodzIK et al. 2017). 1 - within the site No. 10; 2 - within the site No. 14 with a small embankment visible in the field - a forest-farmland border. Phot. B. Niezabitowska-Wiśniewska 


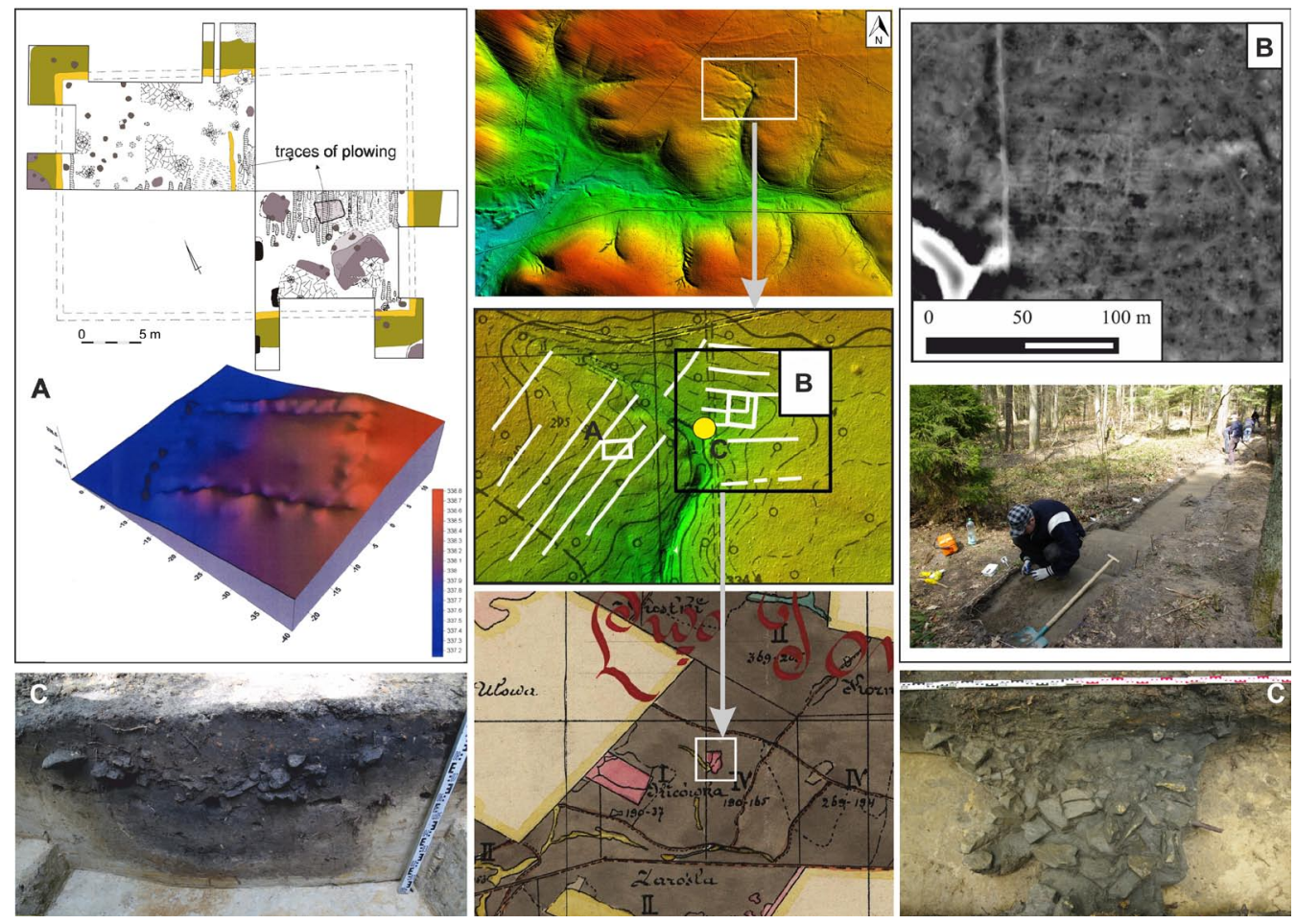

Fig. 9. Remains of the Modern Age settlement $\left(17^{\text {th }}-18^{\text {th }}\right.$ centuries $)$ in the form of plowing traces visible in the DTM image (according to RoDzIK et al. 2017) and two rectangular constructions surrounded by a embankment and a groove, excavated to a varying degree and visible in the DTM image. A - site No. 9; B - site No. 6; C Site No. 6, partially excavated building from the $17^{\text {th }}$ century. B, C - the area marked in the Collective Plan of the Zamoyski Family Fee Tail and marked as arable fields. Fig. and phot. B. Niezabitowska-Wiśniewska; Collective Plan of the Zamoyski Family Fee Tail, http://zamosc.ap.gov.pl/p,3,plan-ordynacji

dated artefacts from so-called Ulów collection. However, the exact location of their discovery is unknown (Fig. 7A: 3).

The remains of the $17^{\text {th }}$ century modern settlement, very well represented in archaeological sources, are located in two zones. The most representative artefacts originate from the hilltop part, where fragments of $17^{\text {th }}$ century building foundations were discovered (site No. 6) (Fig. 9C). Such dated settlement was also recorded in the centre of modern Ulów, where the remains of $18^{\text {th }}$ century buildings, related to the oldest stage of the village architecture was discovered (site No. 27) (Fig. 7B).

In the centre of modern Ulów, in the valley with small pond, and west of it, on a backyard of one of the estates, a large number of melted glass and glass slag has been discovered. They are probably related to the glassworks from the $17^{\text {th }}$ and $18^{\text {th }}$ (?) centuries (site No. 27) (Fig. 7B).

Most probably to the $17^{\text {th }}-18^{\text {th }}$ centuries settlement should also be related the remains of two partially excavated and visible on the surface objects, in the form of rectangular squares surrounded by an embankment and a small groove. One of them 
is located on a large plateau within the site No. 9 and has dimensions of $22 \times 30 \mathrm{~m}$. Within it, traces of ploughing were discovered, not extending beyond the range of the embankment and destroying the located below remains of the Roman Period settlement (NiEZABITOWSKA-WIŚNIEWSKA 2008: 85-87, fig. 12). In the DTM image, in the vicinity of this construction, a group of narrow SW-NE oriented fields is visible, located on the gentle slope of the Zierąbek valley, on its western side (Fig. 9A). The second rectangular object, measuring $42 \times 52 \mathrm{~m}$, is located at site No. 6 in a lower ground, on the eastern side of the Zierąbek valley. NW part of this object was additionally separated by a line of double embankments and a groove. In its vicinity, the DTM image reveals the traces of ploughing in E-W direction (Fig. 9B). Two similar, previously unknown and unexcavated rectangular constructions are located on the hummock between two valleys and are visible on the DTM image (RoDzIK et al. 2017).

In the DTM image there are also visible traces of intensive, modern agricultural activity, located in the area of archaeological sites on the hilltop plateau, in the area covered by the forest. They have the form of long ribbons with the SW-NE direction and widths from a dozen to 40 meters. The compact area of their occurrence is located on the NE from the cluster of archaeological sites. Most probably, the mentioned traces should be related to the $17^{\text {th }}-18^{\text {th }}$ centuries agricultural activity (RoDZIK et al. 2017).

The remains of $19^{\text {th }}$ century settlements, mainly in the form of pottery shards, have been found on almost all archaeological sites located in the forest complex on the plateau, east of the village, as well as on the meadows and fields directly near the modern building of Ulów.

In the micro-morphological DTM image, braided systems of old roads are visible, in most cases currently covered with forest. Most of those located the hilltop are very poorly visible in the field. Roads located on the slopes and recorded in the southern part of the research area, at S from sites No. 10 and 14, are perfectly visible in the field, creating gorges with a depth of up to $1 \mathrm{~m}$ (Fig. 10). They are the result of dirt roads erosion, the course of which was modified after extreme erosive episodes. The old forest growing on them indicates that these forms probably arose in the period of the $17^{\text {th }}-19^{\text {th }}$ centuries intensive settlement (RoDzIK et al. 2017).

Repeated surface surveys in the area of Ulów confirmed, that apart from the complex of sites located in the east (on the hilltop plateau) and south (in the valley) from the modern village, there is no traces of prehistoric settlement. Single fragments of prehistoric ceramics were found only to the west of the village near the Wapielnia hill (about $1.3 \mathrm{~km}$ from the road running through the village). There is also a single burial mound of undetermined chronology (site No. 24) (Fig. 2A, 3). Thus, the current state of research allows to conclude that the intensive prehistoric and modern settlements are focused on an area of about $2.07 \mathrm{~km}^{2}$ (about $207 \mathrm{ha}$ ), and in a radius of at least 2 to $5 \mathrm{~km}$ from it we can talk about deserted settlement area. Therefore, the basic issue regarding the settlement micro-region in Ulów was the answer to the question of why the settlement associated with almost every archaeological culture known from the territories of eastern Poland concentrated on such a small area and was surrounded by areas uninhabited in prehistory or used only sporadically. 

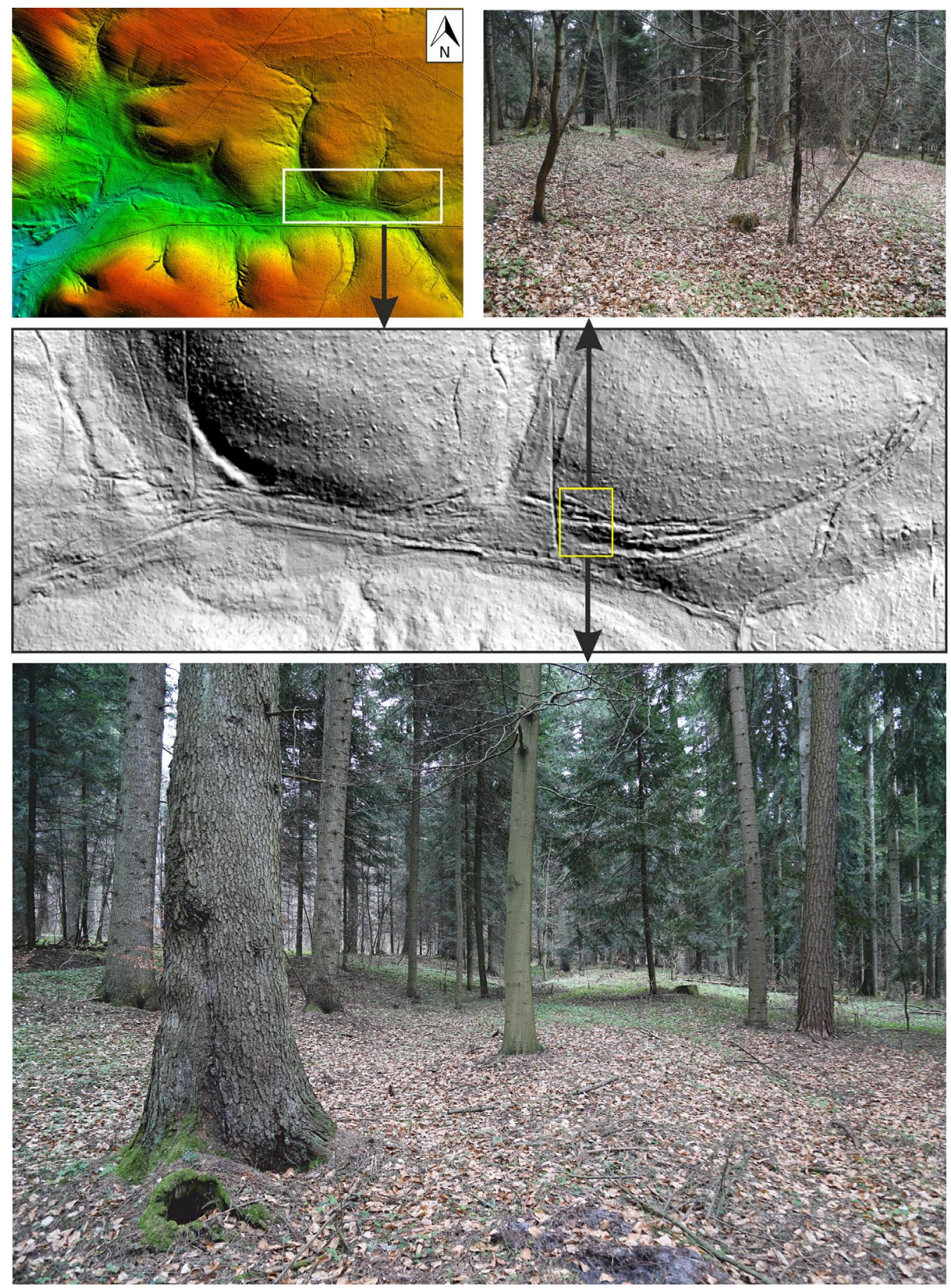

Fig. 10. Traces of the old, Modern Age roads in the southern part of the research area, visible in the DTM image and in the field. Phot. B. Niezabitowska-Wiśniewska 


\section{Environmental conditions of settlement}

The answer to the question about the reasons for the location of the Ulów settlement micro-region gave the results of geomorphological and geological surveys and DTM analysis. The factor that determined the settlement in the area around Ulów by the population of particular archaeological cultures was the constant presence of water near the watershed, in the upper section of the central valley with Zierąbek stream, currently almost dry and flows only periodically (Figs 11,13). The settlement was also conducive to the flatness of land and soil, moderately fertile, but easy to cultivate. The southern exposition of the slopes was also favourable. The relief of the terrain, affecting the development of communication routes in prehistory and in the Early Middle Ages, connecting the Ulów micro-region with neighbouring areas was also of a great importance (RoDZIK et al. 2017; RoDZIK, NiTYCHORUK 2017). NE of Ulów are located the springs of the Wieprz and Sołokija rivers, the first at a distance of about $10 \mathrm{~km}$, the second about $6 \mathrm{~km}$ in a straight line. The valley contiguous the modern village in south, connects with the Łosiniec stream, that flows into Tanwia river, approximately $10 \mathrm{~km}$ away from Ulów. In the near distance there are also the sources of the Sopot river, the inflow of Tanwia river (Fig. 1). In the basins of each of these rivers there was an intensive prehistoric settlement. For prehistoric populations, the possibility of using convenient, natural connections, running on hilltops or through the valleys, had to affect the development of settlement and the inflow of population of particular prehistoric cultures into the Middle Roztocze, including in the area of Ulów.

All observations based on the results of geomorphological and geological research have also been confirmed in archaeological studies. The range of prehistoric settlement exactly coincides with the range of the sands, both on the hilltop plateau and in the bottom of the valley (compare RodzIK, NiTYCHORUK 2017). Detailed analysis of the DTM image allowed to record long, narrow dunes of the E-W and NW-SE direction, very poorly visible in the forested area. Imposing of the maps with the extent of archaeological sites on the DTM image indicates that most of them are located directly on the dunes or between them. Sites located in the bottom of the valley are also related to the aeolian sands in dunes (Figs 3, 12: 4-7).

To the west of the cluster of sites located on the hilltop plateau and north of the sites in the bottom of the valley, including on the slopes and hills culminations around the modern Ulów, in the area of the "prehistoric deserted settlement" a opokas and marly opokas occurs. On a large surfaces, these rocks are exposed, which is visible on almost all the fields around the village. The surface layer of the opokas is strongly weathered and cracked (Fig. 12: 1-2). While the presence of this rocks, or relatively stable soil, is not an impediment in the construction today, in the prehistory it had to affect the lack of interest in these areas. Small enclaves with no traces of prehistoric settlement were also observed "inside" the cluster of sites on the hilltop plateau. They are located mainly at the culmination of the hilltop, where during the excavations under a layer of humus with a thickness not exceeding $10-15 \mathrm{~cm}$, the presence of bedrock was found, excluding the presence of residential or sepulchral prehistoric 

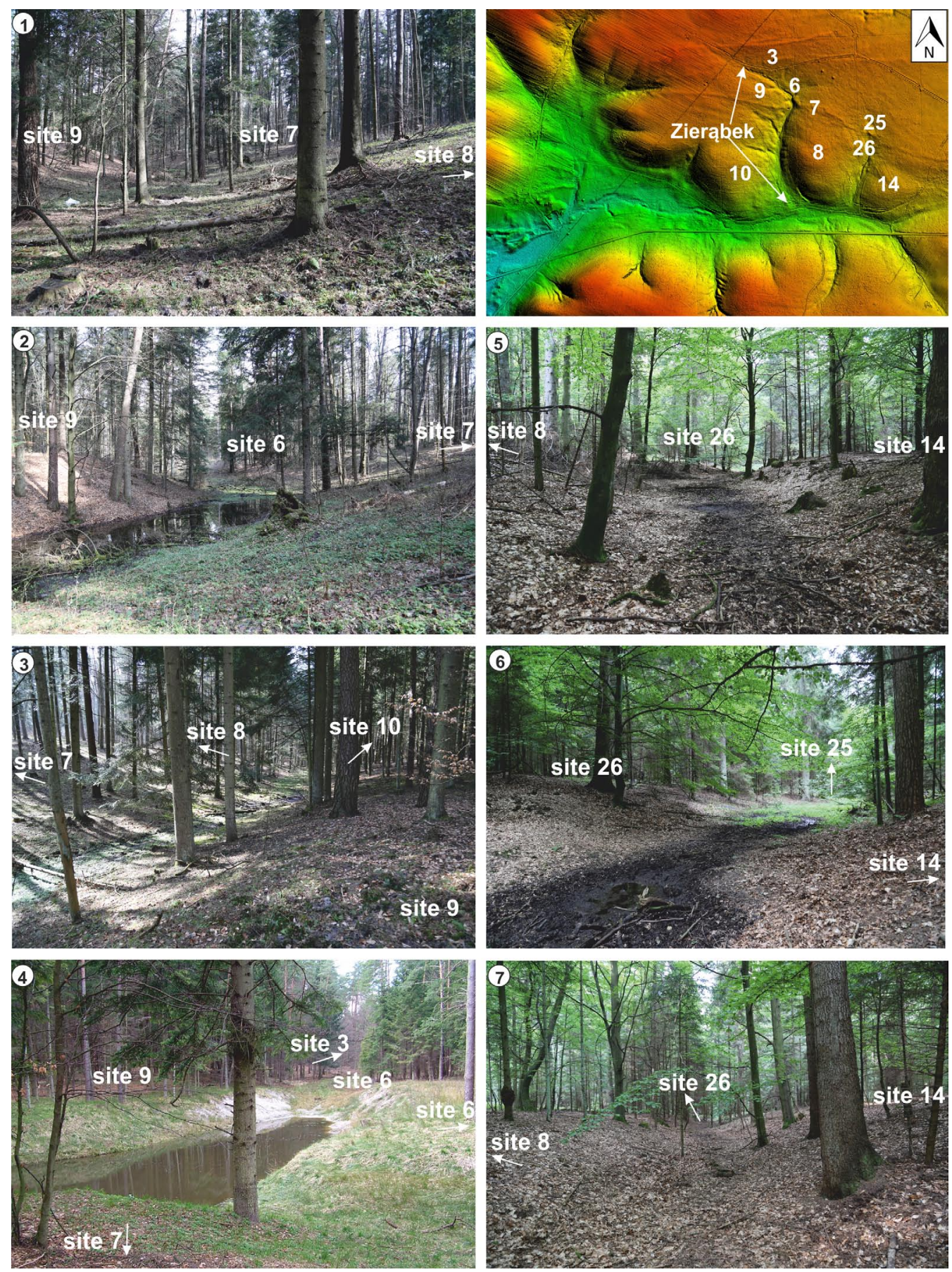

Fig. 11. Location of archaeological sites in the hilltop plateau area in relation to the course of the two main valleys. 1-4 - Zierąbek valley (4 - artificial fire-fighting tank); 5-7 - so-called side valley. Phot. B. Niezabitowska-Wiśniewska 
features (Fig. 12: 3). These observations have helped to narrow the range of some of the archaeological sites (No. 7, 8, 10) determined by the militaria hunters. However, it cannot be excluded, that these areas were used agriculturally, forming the economic base for the settlements located on the sands around the Zierąbek stream valley. It can be confirmed indirectly by the already mentioned traces of prehistoric fields visible in the DTM image within the sites No. 10 and 14 (Fig. 8).

\section{Dating of particular cultures}

During archaeological research, difficulties in interpreting particular cultural phenomena or the dating of archaeological features were encountered many times, especially in relation to the multicultural site No. 3 (MosKAL-DEL Hoyo et al. 2017). Hence, a strong emphasis was put on radiocarbon dating. A small number of preserved organic materials, resulting from specific soil conditions, including, among others, the lack of preserved bones in skeletal graves, caused that the most of the dates was obtained from
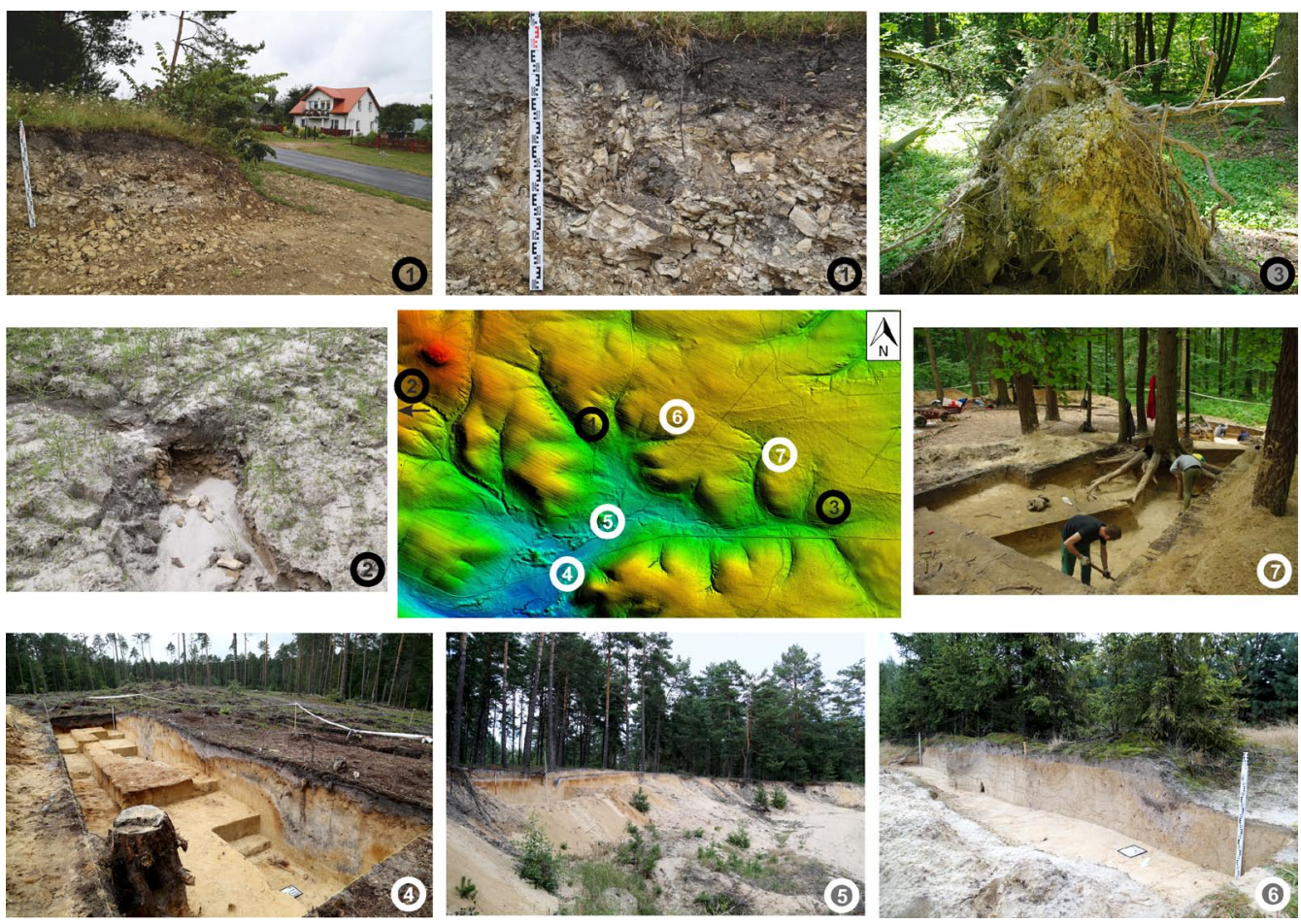

Fig. 12. Differentiation of the soil conditions in the Ulów micro-region; black circles - unfavourable conditions for prehistoric settlements, manifested by the presence of opokas directly under the humus layer; white circles favourable conditions for prehistoric settlement, manifested by the presence of sands. 1 - the centre of modern Ulów; 2 - Łuszczacz surroundings; 3 - hilltop culmination in the centre of the site No. 14; 4-site No. 20, burial mounds on the dune at the bottom of the valley; 5 -dune near site No. 21; 6- site No. 17, sand-quarry section with visible damaged FBC features; 7 - site No. 7 during exploration. Phot. B. Niezabitowska-Wiśniewska 

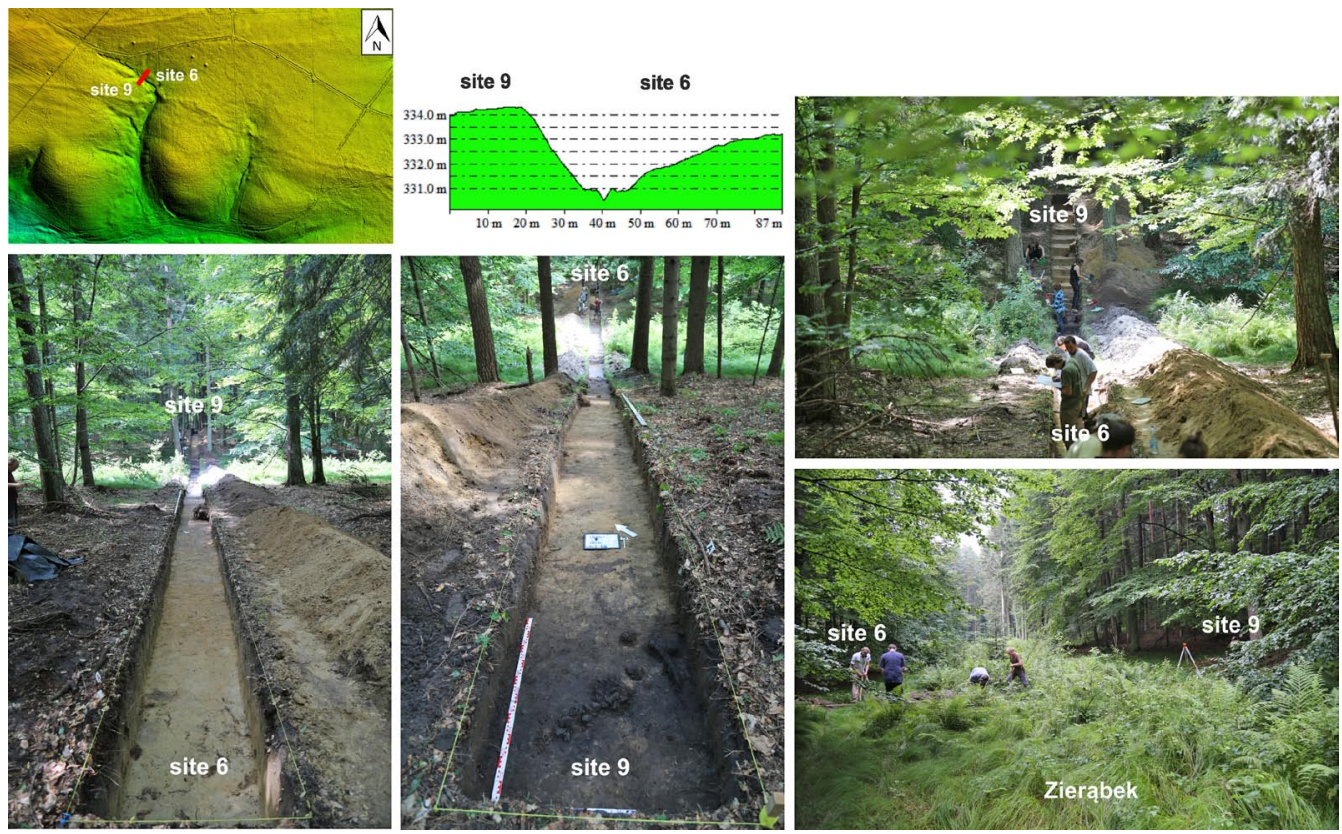

Fig. 13. Trench through the Zierąbek valley. Phot. B. Niezabitowska-Wiśniewska

the charcoal samples. In total, we have 90 radiocarbon dates ${ }^{4}$, including: 50 AMS dates (Poznan Radiocarbon Laboratory); 37 conventional LSC dates (Absolute Dating Laboratory, Marek Krąpiec; GADAM Centre of Excellence, Gliwice Absolute Dating Methods Centre); 3 OSL dates (GADAM Centre of Excellence, Gliwice Absolute Dating Methods Centre). Radiocarbon dates have been obtained for the majority of excavated archaeological sites, including; for site No. 3 - 43 dates (MosKal-Del Hoyo et al. 2017); site No. 4 - 7 dates; site No. 5 - 2 dates; site No. 6 - 2 dates; site No. 7 - 12 dates; site No. 9 - 2 dates; site No. 17 - 1 date; site No. 20 - 2 dates; site No. 21 - 2 dates; site No. 22 - 1 date; site No. 25 - 1 date; site No. 26 - 2 dates. Three OSL dates, one LSC date and one AMS date were obtained for the dune situated at north from the site No. 21; 8 LSC dates for samples from palynological cores (compare PIDEK et al. 2017).

Radiocarbon dates confirm almost every settlement phase recorded in the Ulów micro-region. The chronological range of Palaeolithic and Mesolithic settlement can be defined as $11490-6407 \mathrm{BC}^{5}$ (see WiśNIEWSKI 2017).

The FBC settlement is confirmed by one radiocarbon date (3625-3378 BC). We also have a series of 18 dates documenting the CWC settlement. We can include it in the range 3310-2307 $\mathrm{BC}$.

\footnotetext{
${ }^{4}$ Six more samples will be dated by the end of 2017, which will give a total number of 96 radiocarbon dates for the Ulów settlement complex.

5 Calibrated radiocarbon ages ( $\mathrm{cal} \mathrm{AD} / \mathrm{BC}$ ) were obtained based on the IntCal13 radiocarbon calibration dataset (REIMER et al. 2013) and the OxCal 4.2 calibration software (Bronk RAmSEY 2009). All calibrated ${ }^{14} \mathrm{C}$ dates were stated with a $68.2 \%$ probability.
} 
At the current stage of research, there is lack of radiocarbon dates for the features related to the Bronze Age and the early Iron Age. However this chronological horizon is probably documented by a single date obtained from the palynological core (17651510 BC) (compare PIDEK et al. 2017), from the layer containing a large number of charcoal recorded on the dune at north from site No. 21 (791-571 BC) and from the filling of CWC grave on site No. 21 (735-415 BC).

A representative group of radiocarbon dates ( 23 dates) confirms the intensive settlement in the Roman Period and in the early phase of the Migration Period. Two horizons of absolute dating clearly stand out. The first is in the time range from $68 \mathrm{AD}$ to $235 \mathrm{AD}$ (6 dates); the second from $236 \mathrm{AD}$ to $425 \mathrm{AD}$ (17 dates).

A big surprise is the two dates, which after calibration can be included in the range from $111 \mathrm{BC}$ to $82 \mathrm{AD}$ and three almost identical dates from the range 334-539 AD (horizon IIB on site No. 3) (compare Moskal-Del Hoyo et al. 2017).

We also have 11 dates ranging from around the middle of the $5^{\text {th }}$ to the $9^{\text {th }}$ centuries (429/450-878 AD), which in the functioning chronological divisions correspond to the early and late phases of the Migration Period and initial phases of the Early Middle Ages.

Nine absolute age markings can be related to the Medieval Period $\left(14^{\text {th }}-15^{\text {th }}\right.$ centuries - 1305-1470 AD), and six dates with a Modern Period (from 1525/1645 AD).

Obtained radiocarbon dates, on the one hand, have made it possible to specify the chronology of a large group of archaeological features, but on the other, they have highlighted the whole series and complexity of problems linked to their interpretation and relation with archaeological dating of cultural processes and phenomena. Due to the complexity of the topic requiring a full presentation of archaeological sources, this article will only indicate the biggest of surprises related to the results of radiocarbon dating.

At site No. 3, eight rectangular-shaped or close to it features were found, 1.5 to $2.20 \mathrm{~m}$ long, 0.9 to $1.5 \mathrm{~m}$ wide and 0.7 to $1.10 \mathrm{~m}$ deep. They contained a burnt wooden beams and very small bone fragments, sometimes taking the form of "dust", which made it impossible to obtain them for further research. In the ceilings of these features occurred a small amount of multicultural artefacts in the form of ceramics shards, which did not allow to specify their chronology (Fig. 14). These objects were initially considered to be funeral pyres (ustrinum) related to the cemetery of the Wielbark culture. This was indicated by their structure, the presence of burned human bones and the location within the site - north and south of the concentration of this culture graves (NiEZABITOWSKA-WiśNiEWsKa 2008: 77). Similar features are also known from other sites dated to the Roman Period (e.g. Madyda-LegutKo et al. 2002; ZaGóRSKA-TELEGA 2015). Anthracological research has allowed to determine wooden beams obtained from the area as made of oak. However, the share of oak in the charcoal samples obtained from the cremation graves of the WC was insignificant, with the clear dominance of the birch. The series of eight radiocarbon dates obtained for features with burnt wooden beams ranges from $3310 \mathrm{BC}$ to $2779 \mathrm{BC}$ and indicates their Neolithic chronology. Hence, with very high probability they should be related with the CWC (horizon I on site No. 3; MosKal-DEL Hoyo et al. 2017). Similar absolute 


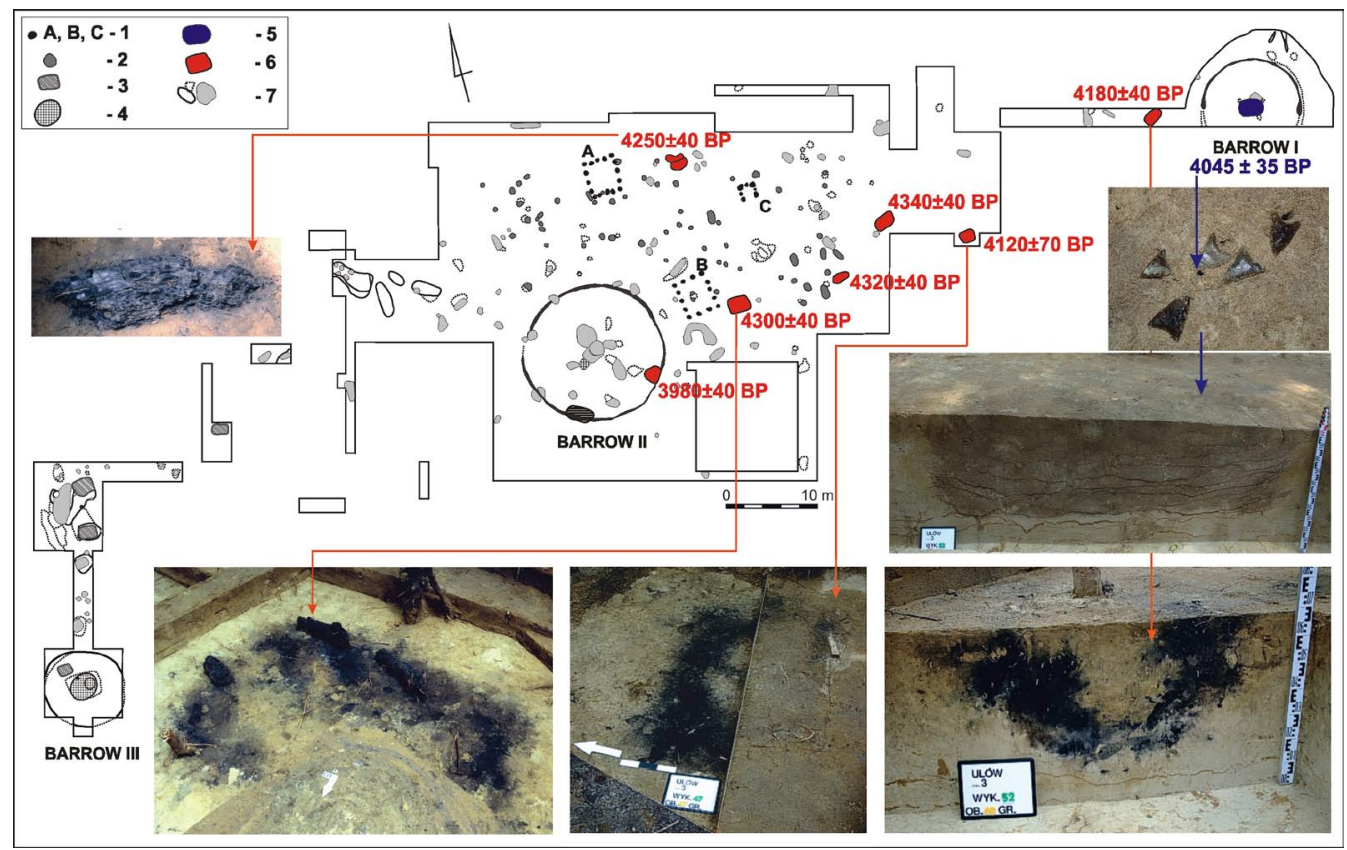

Fig. 14. Plan of the site No. 3 with the location of radiocarbon dated CWC features. 1 - three rectangular pillar constructions; 2 -WC graves; 3 -WC hearths with stone pavement; 4 - CWC under-barrow central graves (barrows No. 2 and 3); 5 - radiocarbon dated, central under-barrow grave in the barrow No. 1; 6 radiocarbon dated CWC features containing burnt oak beams; 7 - other objects (Neolithic, Bronze Age, Early Middle Ages, Modern Age). Fig. and phot. B. Niezabitowska-Wiśniewska

age determinations were obtained for charcoal samples from the CWC central burial pit in barrow 2 on site No. 4 .

Within the site No. 3, three groups of features were discovered - postholes spaced on the plan of three rectangles (structures $\mathrm{A}, \mathrm{B}$ and $\mathrm{C}$ ). Two of these rectangular constructions had similar dimensions: about $4.00 \times 3.50 \mathrm{~m} \mathrm{(A)}$ and $4.40 \times 3.80 \mathrm{~m}$ (B). The smallest (C), almost square, had dimensions $1.8 \times 1.7 / 1.8 \mathrm{~m}$. They were all oriented exactly to the directions of the world. In the case of two larger structures, the number of pillars forming each wall was the same (structure A -5 pillars; B - 4 pillars in the northern and southern walls, and 5 pillars in the eastern and western walls). In the structure $\mathrm{C}$, there was no middle pillar in the southern wall, in the remaining walls there was 3 pillars in each (Fig. 15). Initially, it was assumed that originally these were above-ground platforms, placed on wooden pales driven into the ground, perhaps functioning for a longer period of time and related to the rituals accompanying or preceding the process of cremation and/or burial. These constructions were connected with the younger phase of the cemetery use by the Wielbark culture, dated back to the early phase of the Migration Period. This was indicated by the observed stratigraphic sequence, including the fact that one of the pillars was driven in the cremation grave of the $\mathrm{WC}$, and the relation with the arrangement of the remaining $\mathrm{WC}$ graves (NiEZABITOWSKA-WIŚNIEWSKA 2008: 77, fig. 2; 2009: 202, fig. 20). Such an 
interpretation was reinforced by the fact that a similar construction was discovered at the Roman Period site in Liebersee, Germany, where it was described as a cult object (BEMMANN 2003: 119-120, 124-125, 145-148, pl. 59, 132:1-6).

Ten radiocarbon dates of two different chronological horizons (245-384 AD and 429-636 AD - horizons IIA and IIC on site No. 3; MosKAL-Del Hoyo et al. 2017) were acquired from the northernmost structure A. For structure B, two radiocarbon dates were obtained, also representing two different chronological horizons (230-330 AD and 614-653 AD - horizons IIA and IIC on site No. 3; MoskAL-DEL Hoyo et al. 2017), and for structure $C$ one radiocarbon date (769-874 AD - horizon IID on site No. 3; Moskal-Del Hoyo et al. 2017). The obtained results allow dating of the structure $\mathrm{A}$ in the range from about the middle/end of the $5^{\text {th }}$ to the beginning of the $7^{\text {th }}$ centuries, with an emphasis on the half of the $6^{\text {th }}$ century; structure B on the $7^{\text {th }}$ century and structure $C$ at the end of $8^{\text {th }}-$ first half of the $9^{\text {th }}$ centuries.

Radiocarbon dates close to the younger chronological horizons of structures $\mathrm{A}$ and $\mathrm{B}$ and to the dating of the structure $\mathrm{C}$ were also obtained for four other features from

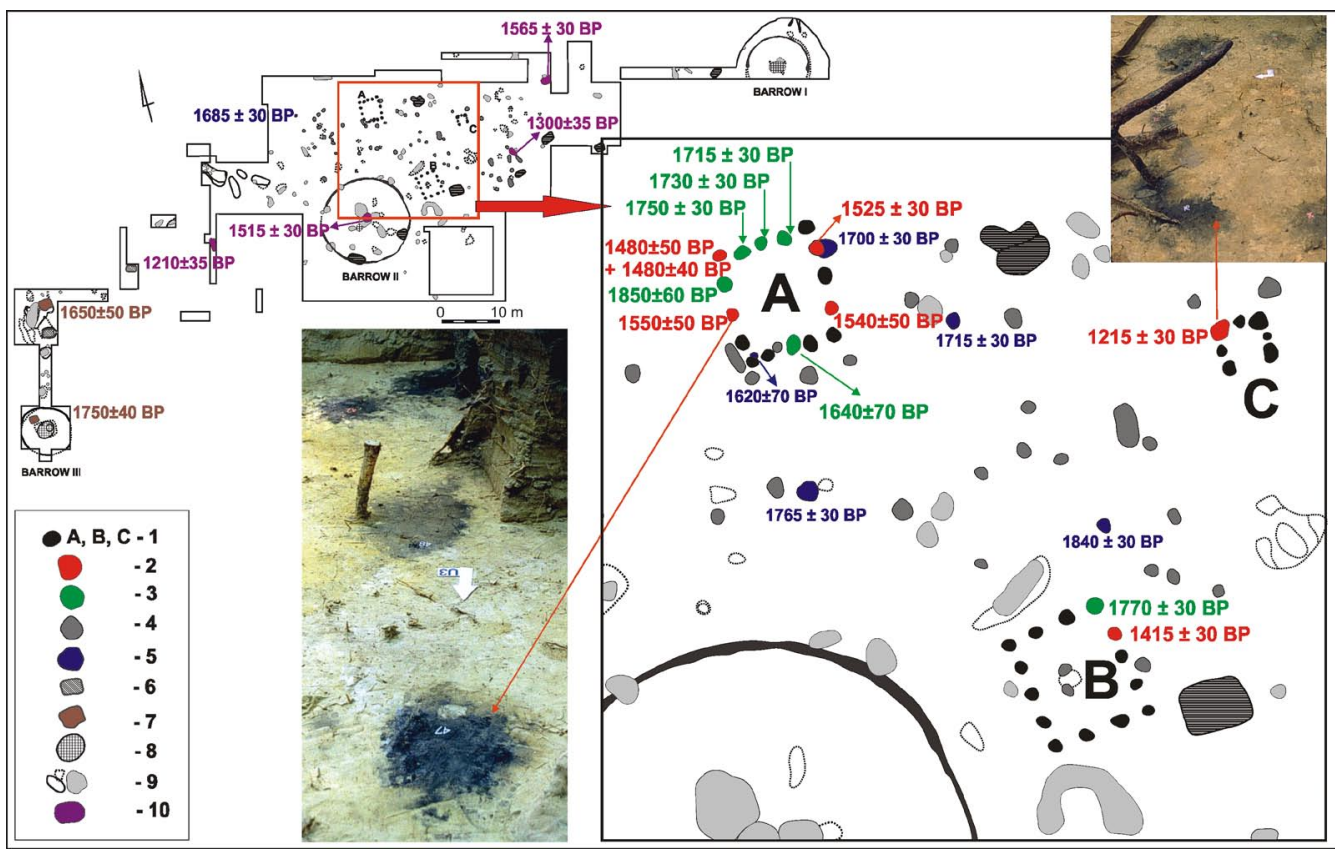

Fig. 15. Plan of the site No. 3 with the location of radiocarbon dated objects for the Roman Period, Migration Period and Early Middle Ages. 1 - three pillar constructions on a rectangular plan; 2 - younger horizon of radiocarbon dates from pillar structures corresponding to the time of their construction; 3 -older horizon of radiocarbon dates from the pillar structures corresponding to the dating of the WC cemetery (dated material originate from the secondary context); 4 - WC graves; 5 - radiocarbon dated WC graves; 6 - WC hearths with the stone pavement; 7 - radiocarbon dated WC hearths with the stone pavement; 8 -CWC under-barrow central graves; 9 - other objects (Neolithic, Bronze Age, Early Middle Ages, Modern Age); 10 - radiocarbon dated features, including those containing burned pine beams, corresponding to the younger horizon of dates from the three pillar structures. Fig. and phot. B. Niezabitowska-Wiśniewska 
site No. 3, including three features containing fragments of burnt, pine wooden beams (429-878 AD) and one pit in the center of CWC burial mound No. 2 (474-600 AD horizons IIC and IID on site No. 3; Moskal-DEL Hoyo et al. 2017).

Radiocarbon dates have also shed a whole new light on a often signaled in the literature large number of wheel-made pottery and their fragments discovered in both cemeteries of the Wielbark culture in Ulów (NIEZABITOWSKA-WiśNIEWSKA 2014b; 2015a). This fact, as well as the morphological characteristics of the wheel-made pottery, force us to put forward a thesis of local production of some of such vessels. These radiocarbon dates obtained for 13 graves containing wheel-made ceramics, form two distinct chronological horizons. The first one can be summed up in the range 68-235 AD; second 254-400 AD (Fig. 16).

\section{CONCLUSIONS AND DISCUSSION}

Without the full presentation of sources, which goes far beyond the scope of the current article, it is not possible to refer in detail to all the results of the research presented in the previous chapter. Therefore, the following conclusions should be treated as a signalling of the problems and initiating the discussions on the settlement phenomenon in the micro-region of Ulów.

\section{Number of archaeological sites, cultural characteristics}

The presence of almost all archaeological cultures known from the area of eastern Poland in the Ulów settlement micro-region, indisputably indicates the attractiveness of this area, regardless of the period in prehistory. The history of research and the degree of recognition of the Ulów micro-region, reveal the validity and even the necessity of research including the recognition of all settlement traces, regardless of their chronology or function. Only this approach allows full reconstruction of the settlement processes and linking them to the environmental conditions. The unique character of the sites cluster in Ulów is also emphasized by the presence of a deserted settlement area around the complex of sites.

The discovery of a new sites at the foot of Wapielnia during the surface surveys or artefacts in Łuszczacz, distant from Ulów by about $4 \mathrm{~km}$, indirectly indicate the possibility of other prehistoric settlement enclaves existing within the Middle Roztocze. One may risk a statement that the current image of the prehistory of this region is rather the result of an insufficient degree of research than unfavourable natural conditions. It is also a proof of the hasty transfer of contemporary ideas about the attractiveness of the place to the prehistoric times.

The history of research in Ulów also reveals the long-term problem of archaeologist's reluctance to study forested areas, related to the need of development a research methodology adapted to these conditions. The interest in the forested areas research gradually increases in recent years, which is reflected, among others, in numerous 

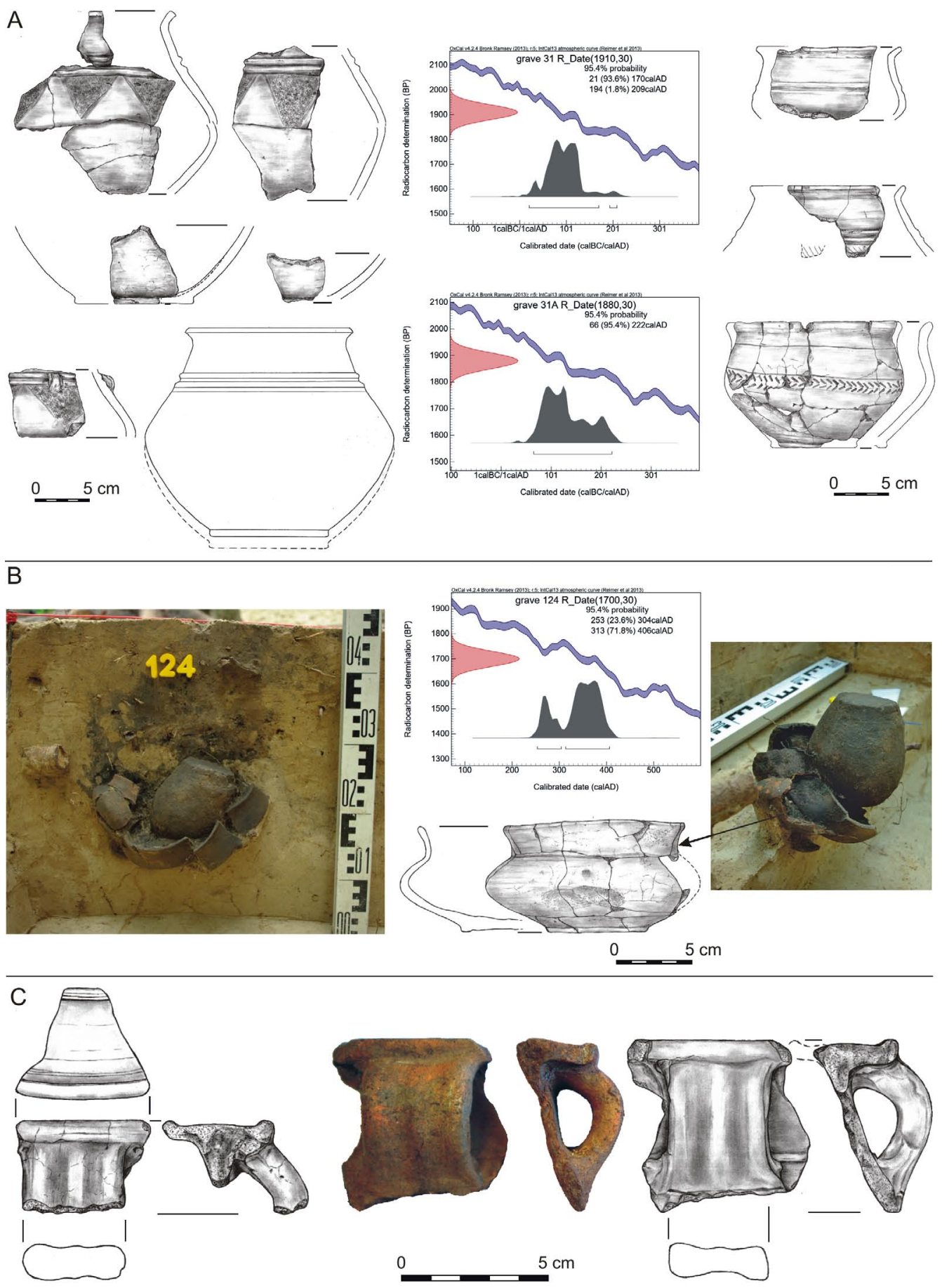

Fig. 16. Site No. 7 - selection of wheel-made pottery from the WC cemetery. A - part of the inventory from the feature (grave) No. 31; B - part of the inventory from the feature (grave) No. 124; C - shards of the Chernyakhov culture pottery originating from the cultural layer. Fig. and phot. B. Niezabitowska-Wiśniewska 
projects or scientific conferences devoted to this issue ${ }^{6}$. An enormous role in this process was played by the easy access to the LIDAR data, thanks to which an unimaginably large number of previously unknown barrows and other traces of the prehistoric settlement, covert in the forests throughout Poland were discovered.

\section{Spreading and environmental conditions}

The spreading of the settlement of particular archaeological cultures in the area of Ulów in most cases perfectly reflects the canons of the habitat selection, known from other areas of Poland. This applies, among others, to Mesolithic sites very often located on dunes near watercourses, or L-VC and FBC sites in south-eastern Poland in a large part located on hilltop plateaus (e.g. KRUK 2008: 91, 92).

In the uplands of south-eastern Poland, the CWC population usually located their barrows in the upper parts of loess hills, avoiding steep slopes and the bottoms of the valleys. From the Lublin region, there are also a few sites located on small heights, within wide river valleys or on their edges. Very rarely, CWC burial mounds were located in a low landscape zones, including terraces in river valleys. They were recorded mainly in Łukawica and Brzezinki. Such location is also characteristic for some of cemeteries of the Middle Dnepr culture and for the part of settlements of the CWC (MACHNIK 1966: 240, 246; JAROSZ 2011: 256, 257; 2016: 509-514).

In the case of CWC from Ulów, we can talk about the specific encounter of these "two worlds". This reflects the fact that the mounds are located in two extremely different zones - on the hilltop plateau and on the overflow terraces in the bottom of the valley. Distinct differences are also visible in a grave equipment and some constructional features of the barrows and burial pits. In the burial mounds on the hilltop plateau, dominate a rich grave-goods including, apart from at least two vessels, also a sets of flint and stone artefacts (compare PyżEwICZ 2017). It is also confirmed that the younger graves of the CWC are embed in the central burial pits (NIEZABITOWSKAWIŚNIEWSKA, WIŚNIEWSKI 2011; in print). The grave-goods from central pits of the barrows located in the bottom of the valley is usually limited to the presence of two clay vessels, and is characterized by a complete lack or a small number of flint artefacts, and a complete lack of stone artefacts.

As it was already mentioned, the valleys of the main rivers of this region, and the valleys of small streams, could play an important role in spreading of the prehistoric settlement to the centre of Middle Roztocze. Perhaps the CWC settlement recorded in the plateau is connected with the population that has came from the north-east, from the Sokal Ridge, where similarly to the Ulów, it constructed its burial mounds in the upland areas (MACHNIK et al. 2001, 2009). The burial mounds located at the bottom of the valley may be related to the population of CWC that came from the south,

\footnotetext{
6 E.g. the third scientific conference "Konserwacja zapobiegawcza środowiska" w rocznicę śmierci prof. Andrzeja Tomaszewskiego "Dziedzictwo kulturowe w lasach" ("Preventive conservation of the environment" on the anniversary of prof. Andrzej Tomaszewski death "Cultural heritage in the forests"), Warsaw, 24-25 October 2013, or the planned conference "Archeologia obszarów leśnych” (“Archeology of forest areas”), Białowieża, April 19-21, 2018.
} 
along the Łosiniec Stream from the upper Tanwia basin, where the burial mounds are located similarly as in Ulów in the bottoms of the valleys (MACHNIK 1966: 240, 246). Indirectly this hypothesis is confirmed by the LIDAR image, where several unexplored clusters of mounds are recorded along the valley of the Tanwia River and Losiniec Stream, wherein the cluster in the area of Ulów is the northernmost enclave of mounds located in the Losiniec Stream valley and its, mostly nameless, inlets (Fig. 1).

The reference to the location of TC sites is quite difficult, mainly due to the relatively small number of artefacts and features that can be attributed to this culture, and the difficulty in determining the nature of such dated settlement in the area of Ulów. The recording of TC traces on small hills within the duned terraces and in the hilltop areas located very close to the valleys, perfectly fits into the conditions observed in other areas covered by this culture settlement. It also reveals the relationship between TC settlement and river valleys, as well as the close hinterland of the valleys (TARAS 1995: 25-33; MAKAROWICZ 2010: 63-80, 207-210, 216).

The presence of L-VC, FBC and CWC settlement in the same places recorded in Ulów, finds many analogies also in other areas of Poland, where the practice of locating CWC burial objects directly at the FBC megalithic constructions is well documented (e.g. WtodARCZAK 2006: 48-50). Similarly as in Ulów, it is difficult to determine the nature of this succession. Perhaps in some regions this is related to the nature of the FBC economy and the deforestation of large areas, later used by the population of CWC (KRUK 1980; recently critically NoWAK 2009: 423-450).

In other areas of Poland, the relationship between the location of CWC sites and the location of MC and TC sites is very often observed. Many TC burial mounds were erected in places previously used as a cemeteries by the CWC population. This fact indirectly strengthens the hypothesis of interpreting the TC grave discovered at site No. 3 in Ulów as a under barrow grave with a damaged mound. TC graves were sometimes also embed in the mounds of earlier CWC barrows (MAKAROWICZ 2010: 81, 82, 213, $218,219)$. Perhaps with this manifestation of the TC funeral rite can be combined the fact of embing TC vessel in the CWC burial mound No. 2 on the site No. 3 in Ulów, and a large number of TC pottery fragments found at the foot of this mound.

LC settlement in many areas of its occurrence is located on a dunes and on sandy terraces in bottoms of a valleys (MoskwA 1976: 139-156). The places of discovery of the few traces of the so-dated settlement in Ulów correspond to this canon.

The selection of places for settlement of the WC population is very diverse and depends on the settlement zone. Not without a significance is also the fact of a relatively small number of this culture researched settlements in comparison with the number of cemeteries recognized by the excavation. However, one can observe the rule of locating WC cemeteries in places clearly separated from settlements, but in relatively close distance to them (e.g. WALENTA 2009). Analogous rules for the location of settlements and cemeteries are also known from the Masłomęcz Group (KoKowsKi 1995; CieŚlak 1983; KoKowski, MaZureK 1988: 297). Thus, it can be recognized that the separation of two distinct zones of sacrum and profanum in relation to the WC settlement in Ulów is part of canons recorded in other areas. The separation of 
these two zones in Ulów is enhanced by the terrain relief and the depth of the valley separating the settlements and cemeteries.

The presence of two WC cemeteries of slightly different nature and dating, spaced only about $300 \mathrm{~m}$ apart from each other, is difficult to interpret. The cemetery at site No. 7 seems to been earlier (from the beginning of the third century AD). However, materials from the $4^{\text {th }}$ and the first half of the $5^{\text {th }}$ century AD were also found there, and are also strongly represented in site No. 3. Thus, the dating of both these cemeteries in Ulów is interwoven. Perhaps it should be combined with two different groups of the WC population or, more likely, they should be treated as a family burial grounds (compare KoKOWSKI, MAZUREK 1988). Unfortunately, due to the lack of bone material and the domination of the cremation funeral rite, it is not possible to conduct a genetic tests to confirm this hypothesis. It is also very difficult to interpret the remains of WC settlement within the meadows in the centre of the modern Ulów village. It is far distant from the concentration of this culture other sites. The nature and the type of discovered material, heavily damaged by modern settlement, can indirectly indicate the settlement character of this site.

The location of a few Early Middle Ages sites in the hilltop area of Ulów fits to very diverse locations of such dated sites in other areas of Poland, including the northeastern Lesser Poland region. For the Early Medieval settlement in the conditions of the upland landscape, the distribution of permanent water reservoirs was of great importance. The settlements were also located along a small and medium rivers, very often at valley springs (HoczYK-SiwKowa 1999: 32-34). The last rule can be referred to the location of the Early Middle Ages settlement at the site No. 3 in Ulów.

The $15^{\text {th }}-16^{\text {th }}$ centuries settlement, witnessed in Ulów mainly by a radiocarbon dates, can be related with such dated, dense colonization of the Middle Roztocze region, as a part of the Bełz Voivodeship in the $15^{\text {th }}-16^{\text {th }}$ centuries. This process was particularly intensified in the area between the springs of Tanwia, Solokija and Wieprz rivers, so also in the area of Ulów. At the beginning of the $15^{\text {th }}$ century, the Vlach colonization began, which resulted in reaching the Roztocze region by the Vallachian population of the pastoral type of economy, inhabiting areas difficult to crops cultivation. In the vicinity of modern Ulów, at the end of the $15^{\text {th }}$ and in $16^{\text {th }}$ centuries, a number of villages were founded, including Rogóźno, Szara Wola (Szarowola) and Losiniec, the last one on the Vlach Law (JANECZEK 1993: 145-172).

Traces of the $17^{\text {th }}$ century settlement can be related to the economy of the Zamoyski Family Fee Tail, established in 1589 (TARNAWSKI 1935; KowalsKi 2009: 182-186). Villages older than Ulów and located in its neighbourhood (Rogóźno, Szarowola, Losiniec) were bought by Jan Zamojski in the 70's and 80's of the $16^{\text {th }}$ century, after which they were included in the Zamoyski Family Fee Tail (Peter 1947: 4-14; JANECZEK 1993: 163). The Ulów was probably founded at the beginning of the $17^{\text {th }}$ century. According to the written sources in 1565 the Uchlowo sacred spot and Niedźwiedzie lake existed here, in whose place the village was founded (CHLEBOwSKI 1892: 787; 1902: 673). Thus, traces of $17^{\text {th }}$ and $18^{\text {th }}$ centuries settlement, discovered in the vicinity of modern village (site No. 27) can certainly be related to the oldest 

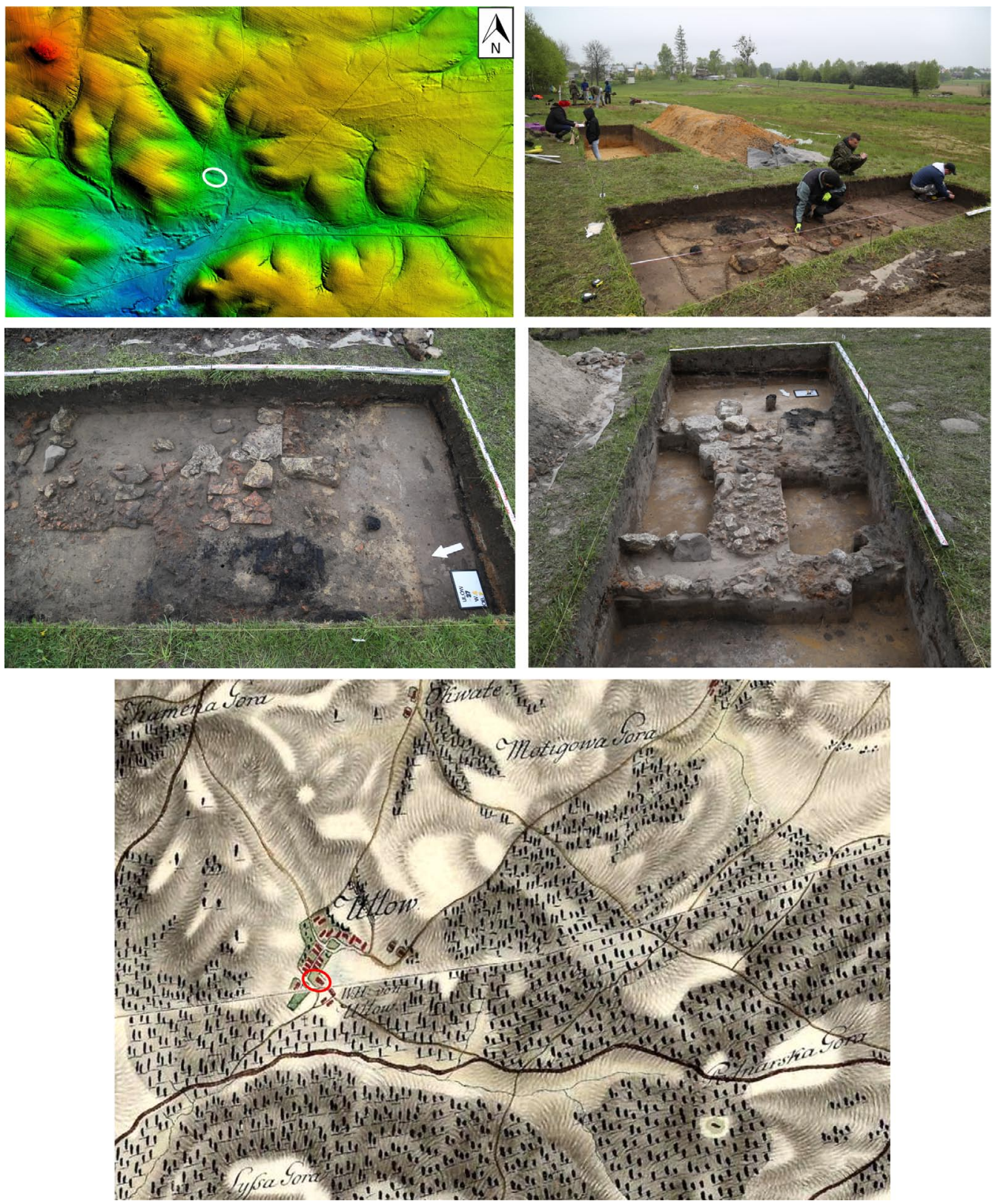

Fig. 17. Site No. 27 - remains of the oldest buildings of the Ulów village in reference to the Topographical Map of the Kingdom of Galician and Lodomeria from 1779-1783. Phot. B. Niezabitowska-Wiśniewska

part of the Ulów village. The location of the building's remains discovered on site No. 27 also coincides with the location of the buildings on the topographic map of the Kingdom of Galicia and Lodomeria from 1779-1783, commonly referred as the Map of Frierdrich von Mieg (Fig. 17). 
It is difficult to clearly determine the function of the building dated to the $17^{\text {th }}$ century, discovered in the hilltop part in a slight depression near the valley of the Zierąbek Stream. Very rich historic material consisting of fragments of ceramics, glassware and metal artefacts, including coins, suggests the possibility of its interpretation as an inn. However, such an inn location does not appear on any of the archival maps. At a distance of $44 \mathrm{~m}$ on the NE from the mentioned building there is one of the rectangular structures, surrounded by a embankment and a groove. In the DTM image are also visible the traces of fields of the E-W direction. Their range perfectly coincides with a range of fields belonging to the Zamoyski Family Fee Tail, visible on the plan drawn up on the basis of measurements from the years 1875-1906 (PRZEGON 2004, collections of the State Archive in Zamość ${ }^{7}$ ) (Fig. 9C). Most probably, this plan deviates slightly from the distribution of the Family Fee Tail goods in the $17^{\text {th }}$ century, from the time before the appropriation of the peasant lands. Therefore, it cannot be excluded, that it was a mid-forest enclave, related with the economic activity of the Zamoyski Family Fee Tail. Thus, it is likely that the second structure, surrounded by a embankment and a groove at a distance of $180 \mathrm{~m}$ on the SW from the $17^{\text {th }}$ century building, can be related to such dated settlement. This is indirectly indicated by radiocarbon dating of a wooden beam (remains of the pillar?) discovered in the groove of this construction and dated back as the earliest at 1645 AD. In addition, traces of ploughing discovered in its range prove that the area was used for agricultural purposes. The construction itself was established on an earlier WC settlement, destroying some of the older objects. Their remains were discovered both inside the structure, as well as under and outside the embankment.

In the place of the SW-NE field traces located on the NE from the clusters of archaeological sites on the hilltop, on mentioned map of the Zamoyski Family Fee Tail, the range of the Szarowola village acres was marked, in contact with forest areas belonging to the Zamoyski Family Fee Tail. Minor differences between the SW boundary of these fields visible in the DTM image, and the range of the fields belonging to the Szarowola village, most probably indicate that in times before the development of discussed plan (in the $17^{\text {th }}$ and $18^{\text {th }}$ centuries?), agricultural areas were larger than at the end of the $19^{\text {th }}$ century. The farmland was gradually fallowed and forested, which at the moment results in a complete forestation of this part of the research area. This process is indirectly indicated by the analysis of topographic maps from $1779-1932^{8}$.

Numerous fragments of the slag and glass products discovered on the site No. 27 and west of it, within the area of estate No. 42 in Ulów, probably indicate the existence of glassworks in the $17^{\text {th }}$ and perhaps in the $18^{\text {th }}$ centuries. In written sources, it is mentioned only enigmatically (in the years 1660-1666) as a "glassworks in Ulów", without indicating its location (WyROBISZ 1968: 42). The location of the mentioned

\footnotetext{
7 http://zamosc.ap.gov.pl/p,3,plan-ordynacji, access 12.12.2017.

8 Mapster - http://igrek.amzp.pl/result.php?cmd=pt\&locsys=1\&uni=-756791\&box=0.0001\&hideempty $=$ on - access 12.12.2017.
} 
glassworks over the valley, where today is a small pond, provided easy access to the water. In the immediate surroundings at the bottom of the valley and its branches there are also numerous dunes, being an excellent source of raw material for the production of glass vessels.

The network of mentioned roads visible in the southern part of the research area is probably related to the use of the road leading to Ulów in the $17^{\text {th }}-19^{\text {th }}$ centuries, running along the right bank of the main valley and its footing, connecting the village with Tomaszów Lubelski and other towns in the region (Fig. 10). The mouth of the road even today is located in the centre of Ulów, where when running out the forest, it passes along the meadows and meets an asphalt road. In the meadows, the site No. 27 is located, i.e. the oldest, $17^{\text {th }}-18^{\text {th }}$ centuries part of the village. The course of the described road was probably changed, depending on the level of the water in the valley. This process is also perfectly reflected in the present situation. A modern road running at the foot of the valley, right next to the forest and used a dozen or so years ago as a convenient connection with the neighbouring village of Pasieki (Tomaszów Lubelski commune), is currently impassable on a significant stretch. Hence, the traffic, mainly walking, takes place on a more convenient path, trodden within the forest a few meters above the road.

\section{The dating}

Radiocarbon dates obtained of organic materials from the Ulów micro-region in most cases confirm archaeological dating of the sites and cultures discovered there. However, some of them require a broader discussion.

In south-eastern Poland, the beginnings of CWC are dated between 2800-2700 BC. The end of this cultural phenomenon was about 2300 BC. Absolute age estimates, however, are complicated by the two flattening of the calibration curve (plateaux) covering periods $2880-2580 \mathrm{BC}$ and $2470-2200 \mathrm{BC}$. This causes a significant extension of the dating probability ranges of a part of the samples (WŁODARCZAK 2006: 121, 122; 2009; 2016; JAROSZ, WŁODARCZAK 2007). The ${ }^{14} \mathrm{C}$ markings obtained for the CWC settlement in Ulów oscillate between $4430 \pm 40 \mathrm{BP}$ and $3880 \pm 35 \mathrm{BP}$, which gives a time interval from $3310 \mathrm{BC}$ to $2307 \mathrm{BC}$. The oldest dates were obtained for the features initially considered as funeral pyres of the Wielbark culture, recorded at site No. 3 and for the central pit grave under barrow No. 2 at site No. 4. So far, dates older than $4150 \mathrm{BP}$ indicating the turn of the fourth and third millennia $\mathrm{BC}$ were questioned (read rejected) in the context of the CWC settlement (WŁODARCZAK 2006: 123; 2009; 2016: 541). In the case of samples from Ulów, we have seven ${ }^{14} \mathrm{C}$ indications older than $4150 \mathrm{BP}$, which can be included in the range of $4430 \pm 40-4250 \pm 40 \mathrm{BP}$, which after conversion into calendar age corresponds to the dating of the Globular Amphora culture in the Lublin Region. Such "old dates" obtained from objects containing burned oak beams and bereft of distinctive CWC materials could easily be questioned, mainly due to the longevity of these trees, that could give an older date, not related to the time of use of oak by man (so-called old wood problem) - (SCHIFFER 1986). However, 
the situation is complicated by the similar dates obtained from pine charcoal samples (Pinus sylvestris) originating from the central, under-barrow CWC grave from site No. 4 (barrow 2). This problem requires further research and detailed presentation of sources, which goes far beyond the scope of this article.

Thus, at the current stage of research, it can be assumed that relating objects containing burned wooden beams and bone fragments to CWC, especially in the light of almost identical dates coming from the CWC burial mound, does not raise any doubts. The interpretation of these objects function is an another issue. In CWC, the cremation rite occur only occasionally (JAROSZ 2010: 283, 284; 2011: 262; 2016: 517, 518). However, it is difficult to find exact analogies to the described features discovered in Ulów. It cannot be excluded, that this is the result of the research method of CWC barrow sites testing, on which the inter-mound space was rarely studied, focusing only on the barrow banks themselves.

At the moment, it is difficult to clearly explain the presence of two radiocarbon dates for charcoal samples (Quercus sp.), whose calendar age is in the range of 111 $\mathrm{BC}-82 \mathrm{AD}$, obtained for two settlement features from sites No. 6 and 9 in Ulów. This period corresponds to the functioning of the Przeworsk culture, which material traces have not been so far discovered in the Ulów micro-region. Historic material from such dated features can be related to the WC. It cannot be excluded, that in this case we have to deal with the so-called old wood problem.

In the light of archaeological research, the WC population began to settle in the Lublin Region at the end of the $2^{\text {nd }}-$ beginning of the $3^{\text {rd }}$ centuries AD (KoKowsKI 1988b, 1991: 183-207; ANDRZEJOWSKI 2007). Such dated are also the beginnings of the Masłomęcz Group (KoKowsKi 1995: 34-42). The disappearance of WC dates back to around the half of the $5^{\text {th }}$ century AD (KOKOWSKi 2005b, 2009; MĄCZYŃSKA 2007). Initially, the time of the emergence of the WC population in the area of Ulów was stated as earliest as the second half of the $3^{\text {rd }}$ century AD. However, the series of six radiocarbon dates from the cremation graves of this culture can be synchronized with the phase $B_{2} / C_{1}-C_{1 a}$, corresponding to the end of the $2^{\text {nd }}$ - beginning of the $3^{\text {rd }}$ centuries BC. Part of the historical materials may also be such dated. Thus, it can be assumed that the settlement of Roztocze by the population of WC took place much earlier than previously thought and can be related with the first wave of the Goths migration to the south-east.

One of the characteristics features of WC is the lack of domestic production of wheel-made pottery. A small number of such vessels, known from this culture are considered to be imports from areas settled by the people of the Chernyakhov culture and/or Sântana de Mureş culture. The appearance of wheel-made pottery in WC dates back as earliest as the phase $\mathrm{C}_{1 \mathrm{~b}}(210 / 230-260 \mathrm{AD})$ - (KoKowsKi 1988d). In this context, a very large share of such ceramics at WC sites in Ulów is of great concern. The genesis of some of it can be unquestionably connected with the Chernyakhov culture. However, local production of part of these vessels cannot be excluded. This can be evidenced by the presence of an ornament unusual for the Chernyakhov culture, that found numerous analogies in WC hand-made pottery, and the fact that in one of 
the settlement features, the shards of wheel-made pottery, which can be considered as production waste, was discovered.

Most of the objects from Ulów that contain wheel-made pottery, both archaeologically and radiocarbon are dated back to the second half of the $3^{\text {rd }}$ - the first half of the $5^{\text {th }}$ centuries $\mathrm{AD}$, which corresponds with the generally accepted dating of this type of ceramics. Absolute age markings for five cremation graves from Ulów that contained wheel-made pottery, including in one case the whole sets of vessels, oscillate between 68-235 AD. The remaining historical material discovered in these graves was initially dated to phases $\mathrm{C}_{1 \mathrm{~b}}-\mathrm{C}_{2}$, mainly just due to the co-occurrence with the wheel-made pottery (NIEZABITOWSKA-WIŚNIEWSKA 2014b, 2015). However, the chronological frames of these artefacts are quite broad and analogies are also known from graves dated back to the end of the $2^{\text {nd }}-$ beginning of the $3^{\text {rd }}$ centuries AD. In this light, the question arises about the genesis of wheel-made pottery, discovered in such "early" dated graves. Certainly, the influence of the later-developed Chernyakhov culture can be excluded. In the light of the latest findings, it is known that a small amount of wheel-made pottery appeared in the Przeworsk culture already in the phase $\mathrm{B}_{2} / \mathrm{C}_{1}$. In Silesia and Lesser Poland, it became common in the phase $\mathrm{C}_{1 \mathrm{a}}$, and a significant increase in its share took place in the phase $C_{1 b}$ (RoDZIŃSKA-NowAK 2006: 189-192, 202, 203; 2010; MosZCZYŃSKI 2010 - further literature there). However, the morphological analysis of the Ulów pottery does not reveal any similarities to the wheel-made pottery in the Przeworsk culture. It is also not possible to exclude the Dacian origin of the wheel-made ceramics from Ulów, what, however, requires further research. The presence on one of the vessels of an ornament of triangles, alternately roughened and smoothed, characteristic for WC hand-made pottery and dated to phase $\mathrm{B}_{2} / \mathrm{C}_{1}-\mathrm{C}_{1 \mathrm{a}}$, allows to assume that at least this vessel was produced locally by WC population, or by a craftsman who arrived in this area from the Dacian cultural circle, and "copied" the traditional WC ornament.

In the archaeological literature the problem of dating and interpretation of cultural phenomena occurring in Polish Lands in the second half of the $5^{\text {th }}$ century AD, that is after the disappearance of the Przeworsk and Wielbark cultures, has been debated for many years. The often-discussed issue is also problem of so-called "settlement hiatus" preceding the arrival of the Slavs, as the earliest as the end $5^{\text {th }}$ - beginning of the $6^{\text {th }}$ century AD (e.g. Bemmann, Parczewski 2005; Kaczanowski, Parczewski 2005; KoKOWSKI 2009). In this light, a series of radiocarbon dates from objects forming three rectangular constructions on site No. 3 in Ulów are striking. As already mentioned, absolute age markings obtained from two of them form two clearly different chronological sequences, the older of which may be related to the Roman Period, and younger with the late phase of the Migration Period and initial phases of the Early Middle Ages. The precise arrangement of these pole structures indicates that they had to be constructed at one time. The presence of older dates most likely can be related to the fact, that the structures are located at the WC cemetery, in the place where similarly radiocarbon dated cremation graves and a cremation layer occur. Hence, during embedding of some of the pillars, as a result of the cremation graves and the cremation layer infraction, single materials, including charcoal lumps, fall inside of the 
pillar pits. Hence, dates related to the Roman Period should be linked with materials found on the secondary context. The dating of the structures should be based on the youngest absolute age determinations, which allows dating of the structure $\mathrm{A}$ in the range from around the middle/end of the $5^{\text {th }}$ - beginning of the $7^{\text {th }}$ centuries, with an emphasis on the middle of the $6^{\text {th }}$ century; structure B for the first half of the $7^{\text {th }}$ century and structure $C$ at the end of $8^{\text {th }}-$ first half of the $9^{\text {th }}$ centuries.

The attempt to determine the function and cultural affiliation is much more difficult than interpreting the chronological divergences of the rectangular constructions. Certainly they were pillar constructions. Although we do not know their purpose, at the moment it cannot be excluded, that they can be interpreted as a houses of pole construction.

In the $6^{\text {th }}$ and $7^{\text {th }}$ centuries in the south-eastern Poland, early medieval settlement already functioned. Sites related to its earliest phase are also known from the Lublin Region. Although, they are located at a considerable distance from the Roztocze area. The rise of the earliest Early Middle Ages sites in Roztocze presently can be dated back at the $7^{\text {th }} / 8^{\text {th }}$ centuries (Zoll-Adamikowa 1975: 80-91; PARCZEWSKI 1988: fig. 21; 1993; НосZYK-SiwKowa 1999: 19, 20, 93-96).

The predominant form of a residential building in the Early Middle Ages was pit-house or shallow pit-house (e.g. HoczYK-Siwkowa 1999: 36-40). The presence of pole structures was recorded under the banks of Early Medieval mounds (ZoLLADAMIKOWA 1979: 85-103). Their shapes, dimensions and orientation are definitely different from the constructions known from Ulów. In the historical material discovered near the pillar structures in Ulów, no artefacts that can be undoubtedly dated for the Early Middle Ages have been registered so far. Thus, the likelihood of relating them with settlement representing traditions of the Roman Period and the early phase of the Migration Period cannot be excluded. This hypothesis is indirectly reinforced by the discovery of a similar object at the aforementioned site in Liebersee, Germany (Bemmann 2003: 119, 120, 124, 125, 145-148, pl. 59, 132: 1-6). However, at the current stage of research, it is difficult to determine the nature of the alleged German settlement. Perhaps it was a population that did not leave the area of Ulów around the middle of the $5^{\text {th }}$ century AD, along with the population of $\mathrm{WC}$, remaining there until the arrival of the Slavs, perhaps a bit later than in the other areas. One should also take into consideration the possibility of returning of a small group of Germans to the north, in the period after the fall of the Hun state in the Carpathian Basin. In this context, the hypothesis about the alleged Herules settlement in the area of Ulow returns again, in the light of the relation of Procopius of Caesarea, in 512 they began their journey from Moravia to the north (after defeating them by the Lombards in the war of 505-508) (NiEZABiTowska 2003a, 2004 - further literature there). This issue also requires a more detailed discussion, far beyond the scope of this article.

Acknowledgements. The work was funded by the National Science Centre (Poland) allocated for the project based on the decision number DEC-2013/09/B/HS3/03352. 


\section{SUMMARY}

Issues presented in this study should be treated only in the category of a signal of small part of problems related to the attempt to reconstruct settlement processes in the Ulów micro-region. In the light of the results of previous research, the title of the project "Roztocze - the ancient terra incognita?..." acquires a completely different meaning. Certainly, the area around modern Ulów was almost continuously inhabited throughout the Prehistory to Modern Times. The reasons for this state of affairs are to be found in specific, but favorable natural conditions, affecting the creation of a settlement enclave in many aspects not analogous to other from the areas of Polish Lands.

\section{REFERENCES}

Andrzejowski J., 2007. Pod wodzą Filimera, czyli osadnicy wielbarscy na Mazowszu i Podlasiu. In: FudZIŃSKI M., PANER H. (Eds.), Nowe materiały i interpretacje, stan dyskusji na temat kultury wielbarskiej. Gdańsk: 229-258. In Polish with German summary.

BagiŃska J., Niezabitowska B., 2003. Ulów, Ldkr. Tomaszów Lubelski, Woi. Lubelskie. In: KokowsKi A., Leiber Ch. (Eds.), Die Vandalen. Die Könige - die Eliten - die Krieger - die Handwerker. Ausstellungskatalog, Bevern: 410-411.

BagiŃsKa J., NiezABitowsKa B., 2004. Katalog - Ulów, pow. tomaszowski, woj. lubelskie. In: ANDRZeJowski J., Kокоwsкi A., Leiвer Ch. (Eds.), Wandalowie - strażnicy bursztynowego szlaku. Katalog wystawy w Państwowym Muzeum Archeologicznym, Lublin-Warszawa: 284-286. In Polish.

Balcer B., Machnik J., Sitek J., 2002. Z pradziejów Roztocza na Ziemi Zamojskiej, Kraków. In Polish with English summary.

Bemmann J., 2003. Liebersee. Ein polykultureller Bestattungsplatz an der sächsischen Elbe, band 3, Dresden.

Bemmann J., Parczewski M. (Eds.), 2005. Frühe Slawen in Mitteleuropa. Schriften von Kazimierz Godłowski. Studien zur Siedlungsgeschichte und Archäologie der Ostseegebiete 6, Neumünster.

Biborski M., BibORSKi M.R., 2017. The results of analysis of the chemical composition of glass artefacts from the cemeteries of the Wielbark culture in Ulów, Tomaszów Lubelski district - report, typescript at the Institute of Archeology MCSU in Lublin.

Bronk Ramsey C., 2009. Bayesian analysis of radiocarbon dates. Radiocarbon 51(1): 337-360.

BUDZISZEWSKI J., JAKUBCZAK M., 2017. Rzeźba terenu jak palimpsest - obraz z lotniczego skaningu laserowego - report, typescript at the Institute of Archeology MCSU in Lublin. In Polish.

Budziszewski J., Szubski M., 2017. Kurhany z Ulowa w kontekście studiów regionalnych - report, typescript at the Institute of Archeology MCSU in Lublin. In Polish.

Chlebowski B. (Ed.), 1892. Słownik geograficzny Królestwa Polskiego i innych krajów słowiańskich XII, Warszawa. In Polish.

Chlebowski B. (Ed.), 1902. Słownik geograficzny Królestwa Polskiego i innych krajów słowiańskich $\mathrm{XV} / 2$. Warszawa. In Polish.

CieŚLAK M., 1983. Osada z okresu wpływów rzymskich w Masłomęczu, gm. Hrubieszów (stanowisko 9). Archeologiczne Listy 5: 1-4. In Polish.

Gawrysiak L., 2004. Województwo lubelskie - cieniowana mapa rzeźby. Polskie Towarzystwo Geograficzne, Lublin. In Polish.

GŁADYSZ-JuŚCiŃSKa M., JuŚCiŃSKi M., 2010. Skarby z okresu rzymskiego i wędrówek ludów. In: Banasiewicz-SzyKula E. (Ed.), Skarby Lubelszczyzny. Lublin: 37-72. In Polish. 
GodŁowski K., 1985. Przemiany osadnicze i kulturowe w południowej i środkowej Polsce w młodszym okresie przedrzymskim i okresie rzymskim. Przegląd Archeologiczny 32: 105-155. In Polish with German summary.

Hoczyk-Siwkowa S., 1999. Małopolska Północno-Wschodnia w VI-X wieku. Struktury osadnicze. Lublin. In Polish with English summary.

HubER M., 2014. Zestawienie roczne z przeprowadzonych badań petrologicznych oraz terenowych przeprowadzonych w ramach grantu/ ULÓW Sprawozdanie z przeprowadzonych badań inwentaryzacji kamienia - report, typescript at the Institute of Archeology MCSU in Lublin. In Polish.

JANECZEK A., 1993. Osadnictwo pogranicza polsko-ruskiego. Województwo bełskie od schyłku XIV do początku XVII w. Warszawa. In Polish with English summary.

JAROSz P., 2010. Východoslovenské mohyly - kilka uwag w oparciu o analizę materiałów źródłowych. In: CzopeK S., Kadrow S. (Eds.), Mente et rutro Studia archaeologica Johanni Machnik viro doctissimo octogesimo vitae anno ab amicis, collegis et discipulis oblata (Myślą i łopatą. Studia archeologiczne dedykowane wybitnemu uczonemu Janowi Machnikowi w osiemdziesiątą rocznicę urodzin przez przyjaciół, kolegów i uczniów). Rzeszów: 275-287. In Polish with German summary.

JAROSZ P., 2011. Kurhany kultury ceramiki sznurowej na pogórzach i wysoczyznach karpackich. In: Kowalewska-Marszalek H., Weodarczak P. (Eds.), Kurhany i obrządek pogrzebowy w IV-II tysiącleciu p.n.e. Kraków, Warszawa: 255-277. In Polish with English summary.

JAROSZ P., 2016. Kultura ceramiki sznurowej na Wyżynie Lubelskiej i terenach przyległych. In: JARosz P., Libera J., WŁodarczak P. (Eds.), Schyłek neolitu na Wyżynie Lubelskiej. Kraków: 509-536. In Polish with English summary.

Jarosz P., WŁodarczak P., 2007. Chronologia bezwzględna kultury ceramiki sznurowej w Polsce południowowschodniej oraz na Ukrainie [Absolute Chronology of the Corded Ware Culture in Southeastern Poland and Ukraine]. Przegląd Archeologiczny 55: 71-108. In Polish with English summary.

JaSKanis D. (Ed.), 1996. Archeologiczne zdjęcie Polski - metoda i doświadczenia. Próba oceny. Warszawa. In Polish with English and German summaries.

Kaczanowski P., Parczewski M. (Eds.), 2005. Archeologia o początkach Słowian, Kraków. In Polish, English, German and Russian.

Koкоwsкi A., 1988a. Problematyka kultury wielbarskiej w młodszym okresie rzymskim. In: GuRBa J., Kokowski A. (Eds.), Kultura wielbarska w młodszym okresie rzymskim (materiały z konferencji) I. Lublin: 15-31. In Polish with German summary.

KoKOwsKi A., 1988b. Zagadnienie osadnictwa ludności kultury wielbarskiej na Lubelszczyźnie. In: GURBA J., Koкоwski A. (Eds.), Kultura wielbarska w młodszym okresie rzymskim (materiały z konferencji) I. Lublin: 241-257. In Polish with German summary.

Kокошsкi A., 1988c. Zagadnienie interpretacji kulturowej materiałów z młodszego okresu rzymskiego typu Lukawica. Archeologia Polski 33: 164-191. In Polish with German summary.

Kокоwsкi A., 1988d. Ze studiów nad ceramiką wykonaną na kole w kulturze wielbarskiej. In: GuRBA J., KoKowski A. (Eds.), Kultura wielbarska w młodszym okresie rzymskim (materiały z konferencji) I. Lublin: 157-176. In Polish with German summary.

Koкоwski A., 1991. Lubelszczyzna w młodszym okresie przedrzymskim i w okresie rzymskim. Lublin. In Polish with German summary.

Koкоwski A., 1995. Grupa masłomęcka. Z badań nad przemianami kultury Gotów w młodszym okresie rzymskim. Lublin. In Polish.

Koкоwski A., 2003. Utracone - odzyskane - zaskakujące. Z Otchłani Wieków, Archeologia Lubelszczyzny, rocznik 58/1-4: 12-18. In Polish. 
Kокоwsкi A., 2005a. Starożytna Polska. Od III w. przed Chrystusem do schyłku starożytności. Warszawa. In Polish with English summary.

KoKowski A., 2005b. Zanik południowych kultur kręgu gockiego. In: KaCzanowski P., Parczewski M. (Eds.), Archeologia o początkach Słowian. Kraków: 165-179. In Polish.

KoKowski A., 2005c. Dwie „bitwy” o Kotlinę Hrubieszowską u schyłku starożytności. Zamość. In Polish.

Kокоwsкi A., 2007a. Ein extraordinärer Fund aus der späten Völkerwanderungszeit im südöstlichen Polen. Acta Praehistorica et Archaeologica 39. Wilfried Menghin zum 65. Geburtstag: 25-33.

Kокоwsкi A., 2007b. Goci od Skandzy do Campi Gothorum (od Skandynawii do Półwyspu Iberyjskiego). Warszawa. In Polish with English summary.

Koкоwsкi A., 2009. Kontinuität und Diskontinuität der Besiedlung in der jüngeren vorrömischen Eisenzeit und in der römischen Kaiserzeit am Beispiel des Hrubieszów-Beckens. Přehled výzkumů 50: $181-212$.

Kokowski A., MAZurek W., 1988. Stanowisko wielokulturowe nr 25 w Moroczynie, gm. Hrubieszów, woj. Zamość. Sprawozdania Archeologiczne XXXIX/1987: 261-307. In Polish with English summary.

Koman W., 2002. Wstępne wyniki sondażowych badań wykopaliskowych w kotlince Bliżowa i w dolinie rzeki Wieprz na odcinku pomiędzy miejscowościami Hutki Namule - Guciów na Roztoczu Tomaszowskim. In: Balcer B., MachniK J., Sitek J. (Eds.), Z pradziejów Roztocza na Ziemi Zamojskiej. Kraków: 165-205. In Polish with English summary.

KowALSKi M., 2009. Państwo magnackie w strukturach polityczno-administracyjnych Rzeczpospolitej Szlacheckiej na przykładzie Ordynacji Zamojskiej. Przegląd Geograficzny 81(2): 173-203. In Polish with English summary.

Koziol K., Czerniec J., Bęgziak B., Orlikowski R., 2012. Archeologiczne Zdjęcie Polski jako element infrastruktury informacji przestrzennej. Roczniki Geomatyki X 4(54): 133-143. In Polish with English summary.

KRUK J., 1980. Gospodarka w Polsce południowo-wschodniej w V-III tysiącleciu p.n.e. Wrocław-WarszawaKraków-Gdańsk. In Polish with English summary.

KRUK J., 2008. Wzory przeszłości. Studia nad neolitem środkowym i późnym. Kraków. In Polish.

Kunisz A., 1985. Znaleziska monet rzymskich z Małopolski. Wrocław-Warszawa-Kraków-Gdańsk-Lódź. In Polish.

MaCHNiK J., 1959. Archeologiczne badania powierzchniowe w południowej Lubelszczyźnie w $1957 \mathrm{r}$. Sprawozdania Archeologiczne 7: 63-73. In Polish with English and Russian summaries.

MACHNIK J., 1960. II sprawozdanie z badań na cmentarzysku kultury ceramiki sznurowej w Łukawicy, pow. Lubaczów. Sprawozdania Archeologiczne 10: 17-22. In Polish with English and Russian summaries.

MachNik J., 1961. Badania archeologiczne w Roztoczu Lubelskim w 1959 r. Sprawozdania Archeologiczne 12: 89-103. In Polish with English and Russian summaries.

MaCHNIK J., 1966. Studia nad kulturą ceramiki sznurowej w Małopolsce. Wrocław. In Polish with French summary.

MACHNiK J., BAGIŃSKa J., Koman W., 2001. Nowa, synkretyczna grupa kultury ceramiki sznurowej w Polsce środkowo-wschodniej. In: Ginter B., Drobniewicz B., Kazior B., NowaK M., Poltowicz M. (Eds.), Problemy epoki kamienia na obszarze Starego Świata. Księga Jubileuszowa dedykowana Profesorowi Januszowi K. Kozłowskiemu. Kraków: 389-399. In Polish with English summary.

MaChNiK J., BagiŃSKa J., Koman W., 2009. Neolityczne kurhany na Grzędzie Sokalskiej w świetle badań archeologicznych w latach 1988-2006. Kraków. In Polish with English summary.

Machniк J., Ротоскі J., 1959a. Sprawozdanie z badań późnorzymskiego kurhanu w Łukawicy, pow. Lubaczów. Sprawozdania Archeologiczne 5: 49-53. In Polish with English and Russian summaries. 
Mаснлік J., Ротоскі J., 1959b. Badania archeologiczne w widłach Sanu i Tanwi w r. 1956. Sprawozdania Archeologiczne 5: 251-257. In Polish with English and Russian summaries.

Madyda-Legutko R., Rodzińska-Nowak J., Zagórska-Telega J., 2002. Pozostałości miejsc kremacji z cmentarzyska kultury przeworskiej w Opatowie, stan. 1, woj. śląskie. In: ANDRZEJowski J., ProchOWicz R., Żórawska A. (Eds.), Varia barbarica. Zenoni Woźniak ab Amicis dicata, Monumenta Archaeologica Barbarica, Series Gemina I. Warszawa-Lublin 2002: 333-352. In Polish.

MAIK J., 2014. Wyniki analiz tekstyliów z cmentarzyska w Ulowie, pow. tomaszowski - report, typescript at the Institute of Archeology MCSU in Lublin. In Polish.

Makarowicz P., 2010. Trzciniecki krąg kulturowy - wspólnota pogranicza Wschodu i Zachodu. Poznań. In Polish with English summary.

MąCZYŃSKa M., 2007. Zmierz kultury wielbarskiej - czego nie wiemy. In: FudZIŃSKi M., PANER H. (Eds.), Nowe materiały i interpretacje. Stan dyskusji na temat kultury wielbarskiej. Gdańsk: 365-401. In Polish with German summary.

Moskal-Del Hoyo M., KrąPIEC M., Niezabitowska-Wiśniewska B., 2017. The chronology of site 3 in Ulów (Tomaszów Lubelski district, east Poland): the relevance of anthracological analysis for radiocarbon dating at a multicultural site. Radiocarbon 59(5): 1399-1413.

Moskwa K., 1976. Kultura łużycka w południowo-wschodniej Polsce, Rzeszów. In Polish with German and Russian summaries.

MoszCZYŃSKi W.A., 2010. Późnorzymska ceramika wykonana na kole na ziemiach polskich. Wybrane problemy. In: MachaJewski H., JuRKiewicz B. (Eds.), Ceramika rzemieślnicza jako źródło do badań nad zróżnicowaniem garncarstwa kultury przeworskiej. Pułtusk: 189-202. In Polish in German summary.

MroczeK P., 2014. Sprawozdanie z badań terenowych w ramach grantu 2013/09/B/HS3/03352 w rejonie stanowisk archeologicznych w Ulowie - report, typescript at the Institute of Archeology MCSU in Lublin. In Polish.

Niezabitowska B., 2003a. Die Heruler. In: Kokowski A., Leiber Ch. (Eds.), Die Vandalen. Die Könige - die Eliten - die Krieger - die Handwerker. Ausstellungskatalog, Bevern: 387-394.

NieZabitowsKa B., 2003b. Ulów - historia wyłaniająca się z mroku lasu. Z Otchłani Wieków. Archeologia Lubelszczyzny 58(1-4): 79-83. In Polish.

Niezabitowska B., 2004. Herulowie. In: Andrzejowski J., Kokowski A., Leiber Ch. (Eds.), Wandalowie - strażnicy bursztynowego szlaku. Katalog wystawy w Państwowym Muzeum Archeologicznym, Lublin - Warszawa: 271-274. In Polish.

Niezabitowska B., 2005a. Prace sondażowe i pierwszy sezon badań w Ulowie, stan. 3, pow. Tomaszów Lubelski. Archeologia Polski Środkowowschodniej VII: 111-122. In Polish with English summary.

Niezabitowska B., 2005b. Zanim przyszli Słowianie czyli Roztocze u schyłku starożytności. In: Banasiewicz-Szykula E. (Ed.), Archeologia Roztocza. Krajobraz przyrodniczo-kulturowy, Skarby przeszłości - Roztocze w pradziejach, Lublin: 73-101. In Polish.

Niezabitowska B., 2007. „Gockie“ osadnictwo z późnego okresu rzymskiego w Ulowie, stan. 3, gmina Tomaszów Lubelski, w świetle znalezisk fibul. In: Fudziński M., PANER H. (Eds.), Nowe materiały i interpretacje. Stan dyskusji na temat kultury wielbarskiej, Gdańsk: 643-665. In Polish with German summary.

NiezabitowsKa-WiśNiewska B., 2007. Ulów - tajemnica starożytnego Roztocza. In: Kokowski A. (Ed.), Ulów - tajemnica starożytnego Roztocza; siódma wystawa Instytutu Archeologii Uniwersytetu Marii Curie-Skłodowskiej w Muzeum UMCS. Lublin: 5-38. In Polish.

NieZABITOWSKA-WiśNiEwska B., 2008. Kompleks osadniczy w Ulowie, powiat tomaszowski - wstępne podsumowanie sześcioletnich badań wykopaliskowych. Archeologia Polski Środkowowschodniej X: 67-93. In Polish with English summary. 
NieZabitowska-Wiśniewska B., 2009. Archaeology, History and the Heruls. The Lublin Region in Late Roman Period and Migration Period. Barbaricum 8, Warszawa: 195-239.

NieZABitowsKa-WiŚNIEwsKa B., 2012. The settlement complex in Ulów, Tomaszów Lubelski Powiat, Lublin Voivodeship - Midway between Scandinavia and the Black Sea. In: KHRAPUNOv I.N. (Ed.), Inter ambo maria. Northern Barbarians from Scandinavia towards the Black Sea. Simferopol: 202-219.

NieZABITOWSKA-WiŚNIEwSKa B., 2014a. Grot brązowy z Ulowa na Roztoczu Środkowym - próba interpretacji. In: MADYda-LegutKo R., RodzińSKa-NowaK J. (Eds.), Honoratissimum assensus genus est arm is laudare. Studia ofiarowane Profesorowi Piotrowi Kaczanowskiemu z okazji siedemdziesiątej rocznicy urodzin. Kraków: 183-193. In Polish with English and German summaries.

NieZABITOWSKA-Wiśniewska B., 2014b. Miniaturowe naczynka wykonane na kole z cmentarzysk kultury wielbarskiej w Ulowie na Roztoczu. In: AndRzejowski J. (Ed.), In medio Poloniae barbaricae. Agnieszka Urbaniak in memoriam. Monumenta Archaeologica Barbarica. Series Gemina III. Warszawa 2014: 163-173. In Polish with German summary.

NiEZABITOWSKA-WiśNIEWSKA B., 2015a. Ulów, stanowisko 7 - nowe cmentarzysko kultury wielbarskiej na Roztoczu Środkowym - z badań nad kontaktami kultury wielbarskiej i kultury czerniachowskiej. In: FUdZIŃSKi M., PANER H. (Eds.), Kontakty ponadregionalne kultury wielbarskiej. Przemiany kulturowe w okresie wpływów rzymskich na Pomorzu. Gdańsk: 331-362. In Polish with German summary.

NieZABITOWsKa-WiŚNiewsKa B., 2015b. Ulów (pow. tomaszowski, woj. lubelskie), stanowisko 7, obiekt 124 - czyli raz jeszcze w kwestii glinianych guzków typu Bernašivka. In: KonTNY B. (Ed.), Ubi tribus faucibus fluenta Vistulae fluminis edibuntur. Jerzy Okulicz-Kozaryn in memoriam, Barbaricum 11, Warszawa 2016: 489-524. In Polish with English summary.

Niezabitowska-Wiśniewska B., Rodzik J., Moskal-del Hoyo M. Barrows of the Corded Ware Culture and their vicinity (Ulów, Tomaszow Roztocze, SE Poland). In preparation for printing.

NiEZABITOWSKA-WiŚNIEWSKA B., WiŚNIEWSKi T., 2011. Kurhany kultury ceramiki sznurowej na stanowisku 3 w Ulowie, powiat tomaszowski. In: Kowalewska-Marszalek H., WŁodarczaK P. (Eds.), Kurhany i obrządek pogrzebowy w IV-II tysiącleciu p.n.e. Kraków, Warszawa: 329-369. In Polish with English summary.

NieZABITOWSKa-WiŚniewsKa B., Wiśniewski T., in print. A new barrow of the Corded Ware Culture in Middle Roztocze (south-eastern Poland). In: WŁodarczaK P. (Ed.), Corded Days in Kraków. Kraków.

NitychORUK J., 2017. Analiza 44 preparatów (płytek cienkich) i świadków wykonanych ze skał pochodzących $\mathrm{z}$ obiektów i warstwy kulturowej z wielokulturowego zespołu stanowisk archeologicznych w Ulowie uwzględnionych w projekcie "Roztocze - starożytna terra incognita..." - report, typescript at the Institute of Archeology MCSU in Lublin. In Polish.

Nitychoruk J., Niezabitowska-Wiśniewska B., Wiśniewski T. Pochodzenie głazów w rezerwacie Piekiełko koło Tomaszowa Lubelskiego, in preparation for printing.

Nitychoruk J., Niezabitowska-Wiśniewska B., Wiśniewski T., Moskal-Del Hoyo M. Geneza piaszczystych osadów pokrywowych w rejonie Ulowa oraz możliwości ich zasiedlania. In preparation for printing.

NowaK M., 2009. Drugi etap neolityzacji ziem polskich. Kraków. In Polish with English summary.

Parczewski M., 1988. Początki kultury wczesnosłowiańskiej w Polsce. Krytyka i datowanie źródeł archeologicznych. Prace Komisji Archeologicznej 27, Wrocław-Warszawa-Kraków-Gdańsk-Łódź. In Polish.

Parczewski M., 1993. Die Anfänge der frühslawischen Kultur in Polen. Veröffentlichungen der Österreichischen Gesellschaft für Ur- und Frühgeschichte 17. Wien.

PaWŁowsKa J., 2017. Sekwencjonowanie amplikonów regionu ITS2 dla grzybów na bazie materiałów z badań archeologicznych kurhanów kultury ceramiki sznurowej w kompleksie osadniczym w okolicach Ulowa - report, typescript at the Institute of Archeology MCSU in Lublin. In Polish. 
Peter J., 1947. Szkice z przeszłości miasta kresowego. Zamość. In Polish.

Pidek I. A., Wasylikowa K., Moskal-del Hoyo M. 2017. Plant exploitation by the inhabitants of the Wielbark culture settlement complex near the village Ulów, SE Poland, at the background of the natural environment. Folia Quaternaria 85: 81-108.

Piotrowski M., 2004. Wybrane zabytki archeologiczne pochodzące z wielokulturowego st. $22 \mathrm{w}$ Łukawicy, w powiecie lubaczowskim. Rocznik Przemyski XL/2: 127-140. In Polish with English and German summaries.

Piotrowski M., 2008. Die spätkaiser- und völkerwanderungszeitliche Siedlung von Łukawica, Kr. Lubaczów. Bericht über die Grabungen 2002-2005 und 2007. In: NiEZABITOWSKA-WiśNIEWSKA B., JuściŃSKI M., Łuczkiewicz P., SAdowski S. (Eds.), The turbulent epoch. New materials from the Late Roman Period and the Migration Period. Monumenta Studia Gothica V. Lublin: 285-294.

PoSPIESZNY Ł., 2015. Sprawozdanie z badań geofizycznych w Ulowie - report, typescript at the Institute of Archeology MCSU in Lublin. In Polish.

Ротоскі J., 1960. Kurhany z okresu rzymskiego w Łukawicy w pow. Lubaczów. Materiały Archeologiczne II: 279-290. In Polish with French summary.

PrZegon W., 2004. Nieznany plan dóbr Ordynacji Zamojskiej w zbiorach Zamojskiego Archiwum. Archiwariusz Zamojski 2004: 7-14. In Polish.

Pyżewicz K., 2017. Use-wear analysis of flint artefacts from the barrows of the Corded Ware Culture in Ulów. Folia Quaternaria 85: 117-134.

Reimer P. J., Bard E., Bayliss A., Beck J. W., Blackwell P. G., Bronk Ramsey C., Buck C. E., Cheng H., Edwards R. L., Friedrich M., Grootes P. M., Guilderson T. P., Haflidason H., Hajdas I., Hatté C., Heaton T. J., Hoffmann D. L., Hogg A. G., Hughen K. A., Kaiser K. F., Kromer B., Manning S. W., Niu M., Reimer R. W., Richards D. A., Scott E. M., Southon J. R., Staff R. A., Turney C., Van Der Plicht J., 2013. Intcal13 and Marine13 radiocarbon age calibration curves 0-50,000 years cal BP. Radiocarbon 55(4): 1869-1887.

Rodzik J., NieZabitowska-WiŚNiewska B., Nitychoruk J., BudZisZewski J., JakUBCZAK J., 2017. Geological and geomorphologic conditions and traces of prehistoric and historic human settlements in the vicinity of Ulów (Roztocze region, southeastern Poland). Studia Quaternaria 34(2): 83-97.

Rodzik J., Nitychoruk J., 2017. Abiotic environmental conditions of former settlement in the vicinity of Ulów in Roztocze (SE Poland). Folia Quaternaria 85: 65-79.

RoDZIŃSKA-NowAK J., 2006. Jakuszowice stanowisko 2. Ceramika z osady kultury przeworskiej z młodszego i późnego okresu wpływów rzymskich i wczesnej fazy okresu wędrówek ludów, Zeszyty Naukowe Uniwersytetu Jagiellońskiego, Prace Archeologiczne 61, Kraków. In Polish with German summary.

RoDZIŃSKA-NowAK J., 2010. Uwagi o chronologii ceramiki wykonanej na kole garncarskim w kulturze przeworskiej w świetle wyników analizy materiałów zabytkowych z osady w Jakuszowicach, woj. świętokrzyskie, i cmentarzysku w Opatowie, woj. śląskie. In: MACHAJEwski H., JURKIEwICz B. (Eds.), Ceramika rzemieślnicza jako źródło do badań nad zróżnicowaniem garncarstwa kultury przeworskiej, Pultusk: 71-87. In Polish with German summary.

RogoziŃSKA R., 1963. Sprawozdanie z badań stanowisk kultury trzcinieckiej w Guciowie i Bondyrzu, pow. Zamość, w 1961 roku. Sprawozdania Archeologiczne XV: 84-93. In Polish with English and Russian summaries.

Rogozińska R., Pотоскі J., 1959. Kurhan z okresu rzymskiego w Łukawicy pow. Lubaczów. Wiadomości Archeologiczne XXVI: 335-337. In Polish.

SCHIFFER Mв., 1986. Radiocarbon dating and the "old wood" problem: the case of the Hohokam chronology. Journal of Archaeological Science 13: 13-30. 
SzCZUROwSKI J., 2017. Skeletal remains from the cemeteries of the Ulów settlement complex $\left(3^{\text {rd }}-5^{\text {th }}\right.$ century AD) - anthropological analysis. Folia Quaternaria 85: 109-116.

Taras H., 1995. Kultura trzciniecka w międzyrzeczu Wisły, Bugu i Sanu. Lublin. In Polish.

TARnAWski A., 1935. Działalność gospodarcza Jana Zamoyskiego kanclerza i hetmana W. Kor. (1572-1605), Lwów. In Polish.

Walenta K., 2009. Leśno i mikroregion w okresie rzymskim. Chojnice. In Polish with English summary.

WILCZYŃSKI J., 2017. Wyniki analizy archeozoologicznej materiałów z badań mikroregionu Ulowa - report, typescript at the Institute of Archeology MCSU in Lublin. In Polish.

WiŚNIEwski T., 2007. Zanim przyszli Germanie. In: NieZABıTOwSKA-WiŚNIEwsKa B., (Ed.), Ulów tajemnica starożytnego Roztocza. Siódma wystawa Instytutu Archeologii Uniwersytetu Marii CurieSkłodowskiej w Muzeum UMCS. Katalog wystawy, Lublin: 39-48. In Polish.

WiŚNIEwsKi T., 2017. The oldest traces of human settlement in the vicinity of Ulów in Middle Roztocze (SE Poland). Folia Quaternaria 85: 49-64.

WŁodARCZaK P., 2006. Kultura ceramiki sznurowej na Wyżynie Małopolskiej. Kraków. In Polish with English summary.

WŁodarczak P., 2009. ${ }^{14} \mathrm{C}$ and dendrochronological dates of the Corded Ware Culture. Radiocarbon 51(2): 737-49.

WŁodARCZAK P., 2016. Chronologia absolutna cmentarzysk późno- i schyłkowoneolitycznych na Wyżynie Lubelskiej. In: Jarosz P., Libera J., WŁodarczaK P. (Eds.), Schyłek neolitu na Wyżynie Lubelskiej, Kraków: 537-548. In Polish with English summary.

Wyrobisz A., 1968. Szkło w Polsce od XIV do XVII w., Wrocław-Warszawa-Kraków. In Polish with French summary.

ZAGÓRSKA-TELEGA J., 2015. Obiekty kremacyjne z cmentarzysk kultury przeworskiej z dorzecza Liswarty z młodszego i późnego okresu wpływów rzymskich oraz z wczesnej fazy okresu wędrówek ludów. Wiadomości Archeologiczne LXVII: 201-246. In Polish with English summary.

Zoll-Adamikowa H., 1975. Wczesnośredniowieczne cmentarzyska ciałopalne Słowian na terenie Polski. cz. I. Źródła, Wrocław-Warszawa-Kraków-Gdańsk. In Polish with German summary.

Zoll-Adamikowa H., 1979. Wczesnośredniowieczne cmentarzyska ciałopalne Słowian na terenie Polski. cz. II. Analiza. Wnioski, Wrocław-Warszawa-Kraków-Gdańsk. In Polish with German summary. 